\title{
Novel inhibitors of the calcineurin/NFATc hub - alternatives to CsA and FK506?

\author{
Matthias Sieber and Ria Baumgrass*
}

\author{
Address: Deutsches Rheuma-Forschungszentrum Berlin, Charitéplatz 1, D-10117 Berlin, Germany \\ Email: Matthias Sieber - sieber@drfz.de; Ria Baumgrass* - baumgrass@drfz.de \\ * Corresponding author
}

Published: 27 October 2009

Cell Communication and Signaling 2009, 7:25 doi:I0.1 I86/I478-8IIX-7-25

This article is available from: http://www.biosignaling.com/content/7/1/25

(c) 2009 Sieber and Baumgrass; licensee BioMed Central Ltd.

This is an Open Access article distributed under the terms of the Creative Commons Attribution License (http://creativecommons.org/licenses/by/2.0), which permits unrestricted use, distribution, and reproduction in any medium, provided the original work is properly cited.
Received: 12 August 2009

Accepted: 27 October 2009

\begin{abstract}
The drugs cyclosporine $\mathrm{A}(\mathrm{Cs} \mathrm{A})$ and tacrolimus (FK506) revolutionized organ transplantation. Both compounds are still widely used in the clinic as well as for basic research, even though they have dramatic side effects and modulate other pathways than calcineurin-NFATc, too. To answer the major open question - whether the adverse side effects are secondary to the actions of the drugs on the calcineurin-NFATc pathway - alternative inhibitors were developed. Ideal inhibitors should discriminate between the inhibition of (i) calcineurin and peptidyl-prolyl cis-trans isomerases (PPlases; the matchmaker proteins of CsA and FK506), (ii) calcineurin and the other Ser/Thr protein phosphatases, and (iii) NFATc and other transcription factors. In this review we summarize the current knowledge about novel inhibitors, synthesized or identified in the last decades, and focus on their mode of action, specificity, and biological effects.
\end{abstract}

\section{Background}

The calcium-dependent serine/threonine (Ser/Thr) protein phosphatase calcineurin, discovered more than 30 years ago [1], is a key factor of a multitude of cell signalling processes, in particular in immune, neuronal and muscle cells. Targeting the phosphatase activity of calcineurin has revolutionized clinical transplantation. Calcineurin represents a hub of antigen specific $\mathrm{T}$ cell activation and differentiation (Figure 1). Inhibition of calcineurin totally blocks the adaptive immune response. Therefore, calcineurin is considered as "Achilles' heel of the immune system" [2].

\section{The Ser/Thr phosphatase calcineurin}

Calcineurin, also named protein phosphatase 2B (PP2B), is a ubiquitously expressed cytosolic Ser/Thr protein phosphatase, highly conserved in eukaryotes. Calcineurin consists of two subunits - the enzymatic subunit A and the regulatory subunit $\mathrm{B}$. The subunit $\mathrm{A}$ contains a calmodulin binding site and an autoinhibitory domain, which blocks the catalytic centre of the enzyme. Binding of $\mathrm{Ca}^{2+}$ ions and calmodulin to calcineurin leads to a change of conformation and a subsequent unmasking of the active centre. Thereby, calcineurin activity is coupled to cytosolic calcium levels, which is a unique property of calcineurin among the Ser/Thr protein phosphatases [3]. Additionally, activity and localization of calcineurin is modulated by endogenous proteins, such as RCANs, Cabin 1 or AKAP79. These regulatory proteins have been recently reviewed in detail $[4,5]$.

\section{Calcineurin and NFATC}

Calcineurin has the ability to dephosphorylate a broad range of proteins [6]. Some of the most important substrates are the transcription factors of the NFATc (nuclear factor of activated T cells) family: NFATc1 to NFATc4 [7]. 


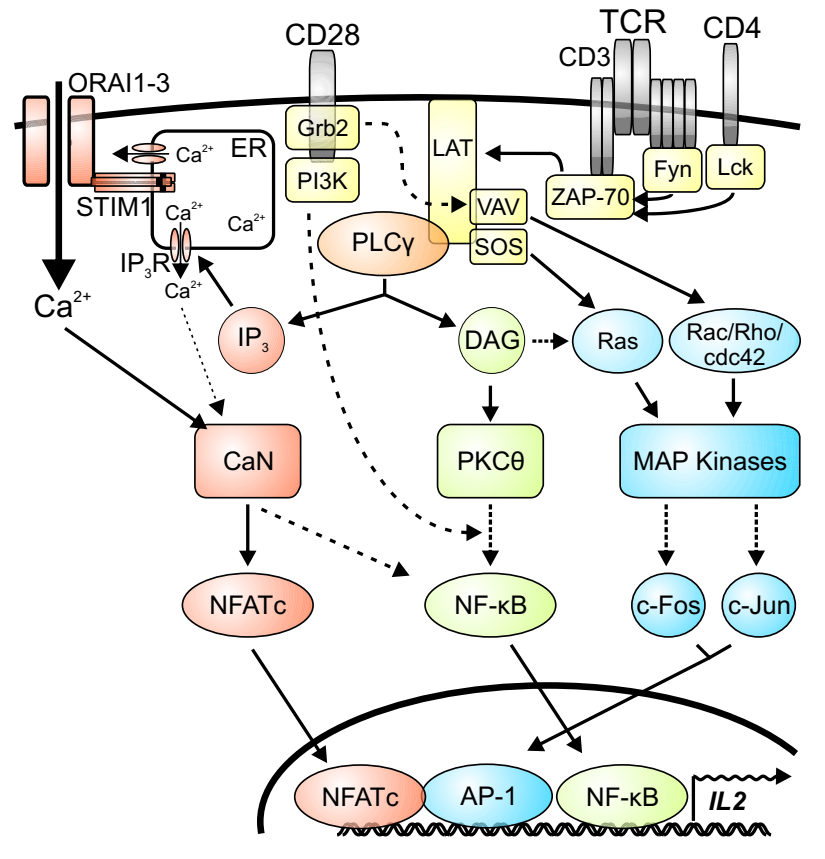

Figure I

Schematic overview about TCR-dependent signalling pathways. Engagement of TCRs and costimulatory CD28 receptors promote signalling cascades of kinases and adaptor proteins (yellow). They trigger pathways resulting in the activation of the transcription factors NFATc (red), NF- $\kappa B$ (green) and AP-I (blue). These transcription factors cooperate with each other during the activation of several genes, e.g. IL-2. Of special interest for this review is the calcineurinNFATc pathway: $\mathrm{IP}_{3}$, generated by PLC $\gamma$ (orange) via cleavage of $P I P_{2}$, binds to the $I_{3}$ receptor $\left(I P_{3} R\right)$ and causes the release of $\mathrm{Ca}^{2+}$ from the endoplasmatic reticulum (ER). This $\mathrm{Ca}^{2+}$ depletion is sensed by STIMI, which is directly coupled to the ORAI CRAC channels. Influx of extracellular $\mathrm{Ca}^{2+}$ into the cytosol activates calcineurin $(\mathrm{CaN})$, leading to the dephosphorylation and nuclear translocation of NFATc. DAG: diacylglycerol; $\mathrm{IP}_{3}$ : inositol- I,4,5-trisphosphate; $\mathrm{PIP}_{2}$ : phosphatidylinositol-4,5-bisphosphate; PKC $\theta$ : protein kinase $\mathrm{C}$ theta; PLC $\gamma$ : phospholipase $\mathrm{C}$ gamma.

NFATc regulates the expression of many genes by binding to DNA as dimers or in cooperation with other transcription factors. Among the regulated genes are cytokines such as IL-2, IL-4 and IFN $\gamma$ or surface proteins such as CD40L and CD95L [8-10]. NFATc controls the expression of the endogenous calcineurin inhibitory protein RCAN1-4, thereby forming a negative feedback loop for the calcineurin-NFATc signalling [11].

Calcineurin seems to be the only protein phosphatase that dephosphorylates NFATc [12-14]. In resting T cells NFATc is highly phosphorylated and localized in the cytosol. Upon stimulation of $\mathrm{T}$ cells and subsequent calcium mobilization activated calcineurin dephosphorylates
NFATc at 13 serine residues in the regulatory region [15], leading to its nuclear translocation by exposure of the nuclear localization sequences $[16,17]$. Concerted rephosphorylation of NFATc leads to its translocation into cytosol and abrogation of NFATc transcriptional activity $[18,19]$.

NFATc is not only dephosphorylated by calcineurin but additionally interacts with calcineurin via two motifs binding at regions distinct from the catalytic centre of calcineurin. These motifs are named calcineurin binding region (CNBR) 1 and CNBR2 or PxIxIT and LxVP according to their consensus sequences, respectively [20]. The PxIxIT region of NFATc binds even to inactive calcineurin and is responsible for basal NFATc-calcineurin interaction $[21,22]$. The LxVP motif interacts just with activated calcineurin, because its binding site at calcineurin is masked by the autoinhibitory domain $[23,24]$. Interaction of both NFATc motifs with calcineurin directs the regulatory region of NFATc into close vicinity to the active centre of calcineurin. This enables targeted dephosphorylation of specific NFATc serine residues by calcineurin. The PxIxIT calcineurin-binding motif of NFATc is shared by several other peptides and proteins binding to calcineurin. This motif may serve as a general calcineurin interface $[25,26]$.

Calcineurin not only modulates the activity of NFATc but also several other transcription factors such as NF- $\kappa \mathrm{B}, \mathrm{AP}-$ 1, and Elk1 [27-33]. In addition, calcineurin interferes with other signalling pathways such as TGF- $\beta$-dependent signalling and the MAPK cascade $[33,34]$. However, it is widely unknown, which components of these pathways are substrates or interaction partners of calcineurin and to which extent their dephosphorylation modulates the respective signalling.

In summary, calcineurin is unique in three aspects. First, it is the only $\mathrm{Ca}^{2+}$-dependent $\mathrm{Ser} / \mathrm{Thr}$ protein phosphatase. Second, to date, only calcineurin is known to activate the NFATc transcription factors thereby controlling the expression of a broad range of genes. Third, the inhibition of calcineurin activity is so far the only effective therapeutic strategy to suppress the activation of memory $\mathrm{CD}^{+}$and $\mathrm{CD}^{+} \mathrm{T}$ cells $[35,36]$. The "classical" drugs targeting calcineurin activity and subsequently inhibiting NFATc activation are cyclosporin A (CsA) and FK506 (tacrolimus). Inhibitors of calcineurin are indispensable for treatment of transplantation patients and represent a valuable tool for basic research.

\section{CsA and FK506 - the classical calcineurin inhibitors}

Cyclosporin A (CsA) and FK506 (tacrolimus) are widely used as effective immunosuppressants in the clinic, mainly in organ transplantation and dermatology [3739]. Application of these compounds in basic research has 
substantially contributed to the elucidation of calcineurin-dependent signalling processes $[40,41]$.

The immunosuppressive properties of CsA were discovered 1976 in animal models [42]. Since 1979 [43,44] CsA is indispensible for transplantation medicine. In 1987, FK506 was described as an alternative to CsA [45], followed by its first clinical application in 1989 [46]. Despite the widespread application of both compounds in the clinics their molecular mechanisms remained unclear until 1991. Then, Liu et al. identified calcineurin as the common target of both compounds if and only if they are complexed with the respective endogenous partners, the immunophilins. They showed that neither the isolated immunophilins nor the immunosuppressants alone but only immobilized immunophilin/immunosuppressant complexes are able to pull down the calcineurin/calmodulin protein from cellular extracts. These experiments clearly demonstrated that CsA and FK506 are not active calcineurin inhibitors by themselves but need binding to their endogenous matchmaker proteins to be activated in a gain of function mechanism $[47,48]$. Immunophilins, belonging to the class of peptidyl-prolyl cis-trans isomerases (PPIases), are involved in de novo protein folding and many other cellular functions $[49,50]$. Binding of CsA or FK506 to their respective major intracellular acceptor proteins cyclophilin A (CypA) and FK506 binding protein 12 (FKBP12) inhibits their PPIase activity. These CsA- and FK506-PPIase-complexes are noncompetitive inhibitors of calcineurin. Thereby, they severely limit the access of protein substrates to the active centre of calcineurin [5154] and mask the docking site for the NFATc LxVP motif at calcineurin [24]. Thus, they inhibit the dephosphorylation of physiological targets of calcineurin. However, small molecular substrates like p-nitrophenyl phosphate (pNPP) are still being dephosphorylated [55,56]. The activity of other Ser/Thr protein phosphatases such as PP1, PP2A or PP2C is not affected by CsA- or FK506-complexes.

Although CsA and FK506 share a similar mode of action, they belong to different chemical classes. CsA is a fungal cyclic undecapeptide [57], whereas the bacterial FK506 belongs to the chemical class of macrolides $[58,59]$.

Application of CsA and FK506 inhibits the T cell receptor (TCR)-dependent activation, proliferation, and differentiation of T cells. Both compounds inhibit the activation of

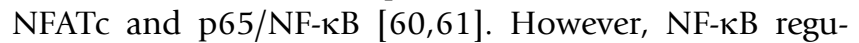
lated gene transcription is not completely blocked, due to additional, calcineurin-independent activation pathways for NF- $\kappa B$ [62]. Other cellular processes, such as CREB transcripitional activity [63] and proteasomal degradation of proteins $[64,65]$, are modulated by CsA or FK506 treatment, too.
So far, CsA and FK506 are the only drugs suppressing not only the activation of naïve and effector $\mathrm{T}_{\mathrm{H}}$ cells, but in addition of memory $\mathrm{T}_{\mathrm{H}}$ cells. Therefore, the application of these drugs is crucial in particular for transplantation patients with high numbers of alloreactive memory/effector T cells, which cannot be controlled with calcineurininhibitor-free treatment protocols $[35,66]$. However, their use in clinical routine is often limited by severe side effects such as nephro- and neurotoxicity [67]. It is not known so far whether these side effects are mainly due to inhibition of calcineurin- or immunophilin-dependent mechanisms. Furthermore, it is not clear whether the modulation of the calcineurin-NFATc pathway or of other pathways and transcription factors cause the adverse side effects.

To dissect the different actions of CsA or FK506, alternative inhibitors should ideally discriminate not only between the inhibition of calcineurin and the other Ser/ Thr protein phosphatases but in addition between the inhibition of calcineurin and PPIases as well as of NFATc and other substrates of calcineurin. Compounds having these properties would be more specific than CsA and FK506 and might cause fewer side effects in clinical applications. In basic research such compounds would help to identify and characterize different targets of calcineurin [68].

Here we review several novel inhibitors of the calcineurinNFATc pathway, which were discovered and partially characterized in the last decades. We summarize these inhibitors according to their mode of action (Figure 2), chemical structure, and inhibitory effects.

\section{Small molecular inhibitors}

Binary complex formation with their respective PPIases is the prerequisite for the ability of CsA and FK506 to inhibit calcineurin. Thus, application of CsA and FK506 does not allow the discrimination between effects of these drugs on calcineurin and on the PPIases, respectively. Therefore, extensive research was undertaken to synthesize or identify derivatives of CsA and FK506 with mono-specificity for either inhibition of calcineurin or of PPIase activity (Table 1).

\section{CsA derivatives}

CsA is a cyclic undecapeptide causing CypA and calcineurin inhibition via different parts of the molecule. CsA residues 2-9 are responsible for CypA binding, while CsA residues 4-7 are involved in calcineurin binding.

Modifications in position 3 [69], position 6 [70,71] or position 8 [72] resulted in some CsA derivatives, such as [(S) $\alpha$-methylthiosarcosine $\left.{ }^{3}\right]$-CsA, [N-Methyl-Ala $\left.{ }^{6}\right]-C s A$ and [D-Diaminopropyl' ${ }^{8}$-CsA, which bind to CypA but 


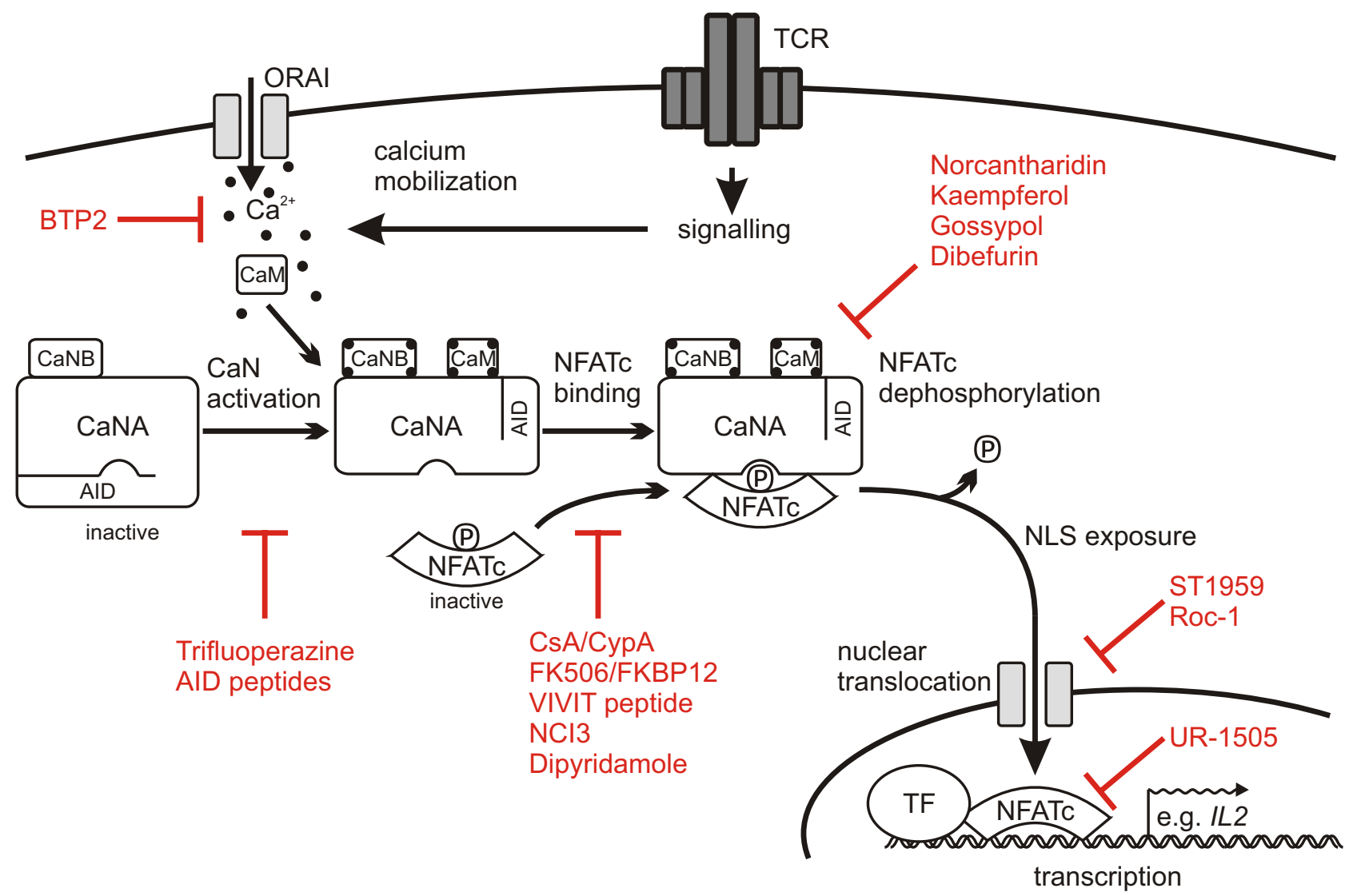

Figure 2

Inhibition of the calcineurin-NFATc pathway at multiple levels. Upon receptor induced $\mathrm{Ca}^{2+}$ entry into the cell, calmodulin $(\mathrm{CaM})$ and calcineurin $\mathrm{B}(\mathrm{CaNB})$ bind $\mathrm{Ca}^{2+}$ ions and activate calcineurin by inducing a conformational switch of the subunit A (CaNA). Activated calcineurin binds NFATc via the PxIxIT and the LxVP motifs of NFATc and subsequently dephosphorylates the transcription factor. Dephosphorylated NFATc exposes its nuclear localization sequence (NLS) and is therefore shuttled into the nucleus, where it binds to the appropriate DNA sequences. NFATc exerts its transactivation effects often in combination with another transcription factor (TF). NFATc is deactivated by rephosphorylation and subsequent translocation into the cytosol. Different steps in this pathway are targeted by certain compounds to finally suppress NFATc-dependent gene expression. A selection of the most important and best characterized inhibitors of calcineurin-NFATc signalling is shown (in red) at their point of interference. AID: autoinhibitory domain of calcineurin A; TCR: T cell receptor.

are not able to inhibit calcineurin's activity, neither in their uncomplexed form nor in the complex with CypA.

Several other CsA derivatives substituted in position 3, e.g. $\left[(R) \alpha\right.$-Methylsarcosine $\left.{ }^{3}\right]$ CsA and [Dimethylaminoethylthiosarcosine ${ }^{3}$ ]CsA have been found to inhibit calcineurin without prior formation of a complex with cyclophilin 18 or inhibition of its isomerase activity. However, both compounds show affinity towards CypA and can therefore not be considered monospecific [73].

Modifications of CsA in the position 1 change the affinity of the derivatives towards CypA. The derivative $\left[\mathrm{MeBm}_{2} \mathrm{t}\right]^{1-C s A}$ has a lower binding affinity than CsA
[74], but the binary complex retains the immunosuppressive capacity. The derivative ISA247 (voclosporin) has a higher affinity to CypA than CsA $[75,76]$ and has the potential to be administered in lower concentrations. Therefore it might be less toxic than CsA and is under investigation in phase II and III trials for psoriasis patients $[77,78]$.

\section{FK506 derivatives}

FK506 has several derivatives with the same mode of action. Among them are the immunosuppressive compounds FK520 (ascomycin) and pimecrolimus. Other FK506 derivatives are monospecific for FKBP12 binding and inhibition, such as L-685,818 (FK506BD) [79] and V- 
Table I: Low molecular weight inhibitors of calcineurin-NFATc signalling

\begin{tabular}{|c|c|c|c|}
\hline Inhibitor & Mode of action & $I C_{50} / K_{d} * / K_{i}^{* *}$ & References \\
\hline \multicolumn{4}{|c|}{ General protein phosphatase inhibitors inhibiting also calcineurin $(\mathrm{CaN})$} \\
\hline Endothall & binds to the active centre of PPI, PP2A, CaN & $11,5 \mu M^{* *}$ a & Tatlock JH 1997 [195] \\
\hline FMPP & binds covalently to the active centre of PPI, PP2A, CaN & $44 \mathrm{mMb}$ & Born TL 1995 [88] \\
\hline Norcantharidin & binds to the active centre of PPI, PP2A, CaN & $31 \mu \mathrm{M}^{\mathrm{b}}$ & Steward SG 2007 [90] \\
\hline Okadaic acid & binds to the active centre of PPI, PP2A, CaN & $4.6 \mu \mathrm{M}^{\mathrm{b}}$ & Bialojan C I988 [196] \\
\hline Tyrphostins & bind possibly to the active centre of $\mathrm{PPI}, \mathrm{PP} 2 \mathrm{~A}, \mathrm{CaN}$ & $21-62 \mu M^{b}$ & Martin BL 1998 [89] \\
\hline \multicolumn{4}{|c|}{ Inhibitors of calcineurin-dependent signalling - CSA, FK506 and derivatives } \\
\hline CsA/CypA & complex blocks substrate access to the active centre of $\mathrm{CaN}$ & $7 \mathrm{nMa}$ & Fruman DA 1992 [197] \\
\hline ISA247/СyрA & complex blocks substrate access to the active centre of $\mathrm{CaN}$ & $\sim 100 \mathrm{nM}^{\mathrm{a}}$ & Aspeslet L 200I [75] \\
\hline$[\text { Dat-Sar }]^{3}-\mathrm{CsA}$ & blocks substrate access to $\mathrm{CaN}$ independent of CypA & $\mathrm{I} \mu \mathrm{M}^{\mathrm{a}}$ & Baumgrass R 2004 [73] \\
\hline FK506/FKBPI 2 & complex blocks substrate access to the active centre of $\mathrm{CaN}$ & $0.4 \mathrm{nMa}$ & Fruman DA 1992 [197] \\
\hline Ascomycin/FKBPI2 & complex blocks substrate access to the active centre of $\mathrm{CaN}$ & $0.7 \mathrm{nMm}$ & Sinclair PJ 1996 [198] \\
\hline Pimecrolimus/FKBPI2 & complex blocks substrate access to the active centre of $\mathrm{CaN}$ & $0.4 \mathrm{nMa}$ & Grassberger M 1999 [82] \\
\hline \multicolumn{4}{|c|}{ Inhibitors of calcineurin-dependent signalling - alternative inhibitory compounds } \\
\hline I,5-dibenzoyloxymethyl-norcantharidin & binds to the active centre of $\mathrm{CaN}$ & $7 \mu \mathrm{M}^{\mathrm{a}}$ & Baba Y 2003 [10I] \\
\hline AM404 & inhibits NFATc-DNA binding & $10 \mu \mathrm{Mc}$ & Caballero FJ 2007 [132] \\
\hline BTPI & inhibits of NFATc dephosphorylation in cells & $60 \mathrm{nMd}$ & Trevillyan JM 200I [118] \\
\hline BTP2 & decreases $\mathrm{Ca}^{2+}$ influx into cytosol & $10 \mathrm{nMc}$ & Ishikawa J 2003 [119] \\
\hline Dibefurin & inhibits enzymatic activity of $\mathrm{CaN}$ & $44 \mu \mathrm{Me}$ & Brill GM 1996 [110] \\
\hline Dipyridamole & disrupts CaN-NFATc binding & $\sim 10 \mu \mathrm{Ma}^{\mathrm{a}}$ & Mulero C 2009 [III] \\
\hline Gossypol & inhibits enzymatic activity of $\mathrm{CaN}$ & $17 \mu \mathrm{M}^{\mathrm{a}}$ & Baumgrass R 200I [199] \\
\hline INCAI & & $0.5 \mu \mathrm{M} * \mathrm{f}$ & Roehrl MH 2004 [II4] \\
\hline INCA2 & $\begin{array}{l}\text { disturb CaN-NFATc complex formation by covalent binding } \\
\text { to } \mathrm{CaN}\end{array}$ & $0.12 \mu \mathrm{M}^{* \mathrm{f}}$ & Roehrl MH 2004 [I I 4] \\
\hline INCA6 & & $0.8 \mu M^{*} f$ & Roehrl MH 2004 [ I I 4] \\
\hline Kaempferol & inhibits enzymatic activity of $\mathrm{CaN}$ & $5 \mathrm{I} .3 \mu \mathrm{Ma}^{\mathrm{a}}$ & Wang H 2008 [94] \\
\hline Liel 20 & inhibits enzymatic activity of $\mathrm{CaN}$ & $5 \mu \mathrm{M}^{\mathrm{a}}$ & Klettner A 200I [80] \\
\hline $\mathrm{NCl} 3$ & disturbs CaN-NFATc binding in cells & $2 \mu M^{c}$ & Sieber M 2007 [1। 3$]$ \\
\hline
\end{tabular}


Table I: Low molecular weight inhibitors of calcineurin-NFATc signalling (Continued)

\begin{tabular}{|c|c|c|c|}
\hline PD I44795 & inhibits enzymatic activity of $\mathrm{CaN}$ & $\sim 3 \mu \mathrm{M}^{\mathrm{a}}$ & Gualberto A 1998 [109] \\
\hline Roc-I & enhances rephosphorylation and nuclear export of NFATc & $5 \sim 25 \mathrm{nMc}$ & Proksch P 2005 [136] \\
\hline STI959/DLIII-IT & enhances nuclear export of NFATc & $13.5 \mu \mathrm{M}$ & Lindstedt R 2009 [128] \\
\hline Thiopental & inhibits CaM-dependent activity of $\mathrm{CaN}$ & $0.18 \mathrm{mM}^{\mathrm{a}}$ & Humar M 2004 [97] \\
\hline Trifluoperazine & inhibits binding of $\mathrm{CaM}$ to $\mathrm{CaN}$ & $8 \mu \mathrm{Mg}$ & Aussel C $1995[144]$ \\
\hline Tropisetron & inhibits $\mathrm{CaN}$-dependent NFATc transactivation & $\sim 50 \mu \mathrm{Mc}$ & Vega Lde L 2005 [138] \\
\hline UR-I505 & inhibits NFATc binding to DNA & $100 \sim 300 \mu \mathrm{Mh}^{\mathrm{h}}$ & Román J 2007 [133] \\
\hline WIN 5307I & alters NFATc binding to DNA & $3.4 \mu \mathrm{Mh}^{\mathrm{h}}$ & Baine Y $1995[|4|]$ \\
\hline \multicolumn{4}{|c|}{ Inhibitors of calcineurin-dependent signalling - unknown mode of action } \\
\hline Caffeic Acid Phenethyl Ester & N.D. & $0,1 \sim 1 \mu \mathrm{Mc}$ & Marquez N 2003 [146] \\
\hline KRM-III & N.D. & $5 \mu M^{c}$ & Jung EJ 2009 [145] \\
\hline NFAT-68 & N.D. & $0.63 \mu \mathrm{Mc}$ & Burres NS 1995 [152] \\
\hline YM-53792 & N.D. & $50 \mathrm{nMc}$ & Kuromitsu S 1997 [149] \\
\hline Punicalagin & N.D. & $<5 \mu \mathrm{Mg}$ & Lee SI 2008 [153] \\
\hline Imperatorin & N.D. & $37 \mu \mathrm{Mc}^{\mathrm{c}}$ & Marquez N 2004 [154] \\
\hline Quinolone alkaloid compounds I and 3 & N.D. & $3.4 \mu \mathrm{Mc}^{\mathrm{c}}$ & Jin HZ 2004 [155] \\
\hline Impressic acid & N.D. & $12.6 \mu \mathrm{Mc}$ & Cai XF 2004 [159] \\
\hline oleanane triterpenoid compound 3 & N.D. & $4.6 \mu \mathrm{Mc}^{\mathrm{c}}$ & Dat NT 2004 [162] \\
\hline Gomisin N & N.D. & $1.33 \mu \mathrm{Mc}$ & Lee IS 2003 [163] \\
\hline
\end{tabular}

N.D.: not determined

Indicated methods for $I C_{50} / K_{d} / K_{i}$ determination: a - phosphatase assay on $R_{\|}$phosphopeptide; $b$ - phosphatase assay on pNPP; $c$ - NFAT dependent reporter gene expression; $d$ - IL-2 promoter dependent reporter gene expression; e - phosphatase assay on 4-methylumbelliferyl phosphate; $f$ displacement of VIVIT peptide; $\mathrm{g}$ - IL-2 secretion assay; $\mathrm{h}$-EMSA for NFATc; $\mathrm{i}$ - interference with CaN-NFATc binding assay; $\mathrm{k}$ - binding assay to $\mathrm{CaN} ; \mathrm{I}$ - phosphatase assay on NFATc; $\mathrm{m}$ - cell proliferation assay

10,367 [80]. However, so far there are no FK506 derivatives with monospecific action on calcineurin.

Several of the immunosuppressive derivatives have been characterized in detail.

FK520 [81] is a naturally occurring FK506 derivative containing an ethyl group in the position 21 and is used as an immunosuppressant in vitro and in rodent models. Several semisynthetic immunosuppressive compounds are derived from FK520. Pimecrolimus (SDZ AM 981, 33epi-chloro-33-desoxy-ascomycin) [82], is routinely used in the topical treatment of inflammatory skin diseases. It is more lipophilic than FK506 and therefore more affine to the skin, has low systemic effects, and does not induce skin atrophy, in contrast to topical steroids. The derivative L-732,531 (32-O-(1-hydroxyethylindol-5-yl)-ascomycin) binds poorly to FKBP12, but the stability of the L732,531-FKBP12-calcineurin-complex is much higher compared to the complex with FK506 [83]. This might be the reason that L-732,531 has less severe side effects in a murine transplant model [84].

Interestingly, FK506 and its related, naturally occurring immunosuppressive compound rapamycin (sirolimus) share the FKBP-binding domain but differ in their effector 
domains [85]. Rapamycin/FKBP12 does not bind to calcineurin [47], but exerts its immunosuppressive and antiproliferative effects via inhibition of the mTOR/Akt signalling. This signalling node is part of costimulatory and IL-2 receptor signalling pathways [86]. Rapamycin is often used in clinical routine in prolonged treatment of transplantation patients after initial CsA or FK506 application. Rapamycin suppresses posttransplantational malignant neoplasia due to its antiproliferative properties [87].

\section{Inhibitors acting on the calcineurin molecule}

The catalytic centre of calcineurin (PP2B) shares the structure and conformation with other Ser/Thr protein phosphatases, namely PP1 and PP2A. Therefore, several inhibitors targeting the active centre of calcineurin additionally inhibit these protein phosphatases, too. Among them are 4-(fluoromethyl)phenyl phosphate (FMPP) [88], tyrphostins [89] and norcantharidin [90]. However, some inhibitors, such as okadaic acid or endothall, show different affinities towards different phosphatases. By using selected concentration ranges of these inhibitors it is possible to inhibit mainly PP1 and PP2A, but calcineurin to a lower degree. Okadaic acid inhibits PP1 and PP2A in nanomolar, but calcineurin in micromolar concentrations [91]. Pyrethroid insecticides do not possess any ability to inhibit calcineurin $[92,93]$, contrary to an earlier report.

The following compounds (Table 1; see additional file 1 for IUPAC names or chemical structures) inhibit calcineurin specifically among the Ser/Thr protein phosphatases. They might act mainly as noncompetitive inhibitors, such as CsA and FK506, but in contrast to them they do not need a matchmaker protein.

Kaempferol, a natural flavonol, inhibits the phosphatase activity of purified calcineurin against pNPP and $\mathrm{R}_{\mathrm{II}}$ phosphopeptide. Kaempferol binds to the catalytic domain of calcineurin A and acts independently of any matchmaker protein. Protein phosphatase 1 and alkaline phosphatase activity are not inhibited by this compound. Kaempferol suppresses IL-2 gene expression in Jurkat T cells [94,95]. Surprisingly, it also inhibits the calcineurin-independent TNF $\alpha$-induced NF-KB activation in HEK293 cells [96].

Barbiturates such as thiopental, pentobarbital, thiamylal and secobarbital are inhibitors of the phosphatase activity of calcineurin [97]. They inhibit the calmodulin-mediated dephosphorylation of the $\mathrm{R}_{\text {II }}$ phosphopeptide [55] in enzymatic assays, as well as NFATc dephosphorylation, NFATc nuclear translocation and cytokine production in $\mathrm{T}$ cells. These effects do not depend on binding of the barbiturates to their GABA receptor and its subsequent signalling. Additionally, barbiturates inhibit AP-1 activation independently of calcineurin [98]. Thiopental suppresses NF-kB activation via unknown mechanisms [99]. In lymphocytes, thiopental decreases antigen- but not mitogeninduced proliferation, IL-2 expression and IFN $\gamma$ expression [100].

1,5-dibenzoyloxymethyl-norcantharidin is a derivative of norcantharidine [101,102]. Among other compounds, it was synthesized according to a computational interaction model of norcantharidin carboxylate with the catalytic centre of calcineurin. It has been selected by screening for specific binding to calcineurin, but not to PP1 and PP2A. 1,5-dibenzoyloxymethyl-norcantharidin inhibits the dephosphorylation of pNPP and the $\mathrm{R}_{\mathrm{II}}$ phosphopeptide by calcineurin. However, no data about inhibition of protein dephosphorylation in cell-free assays or in cells have been reported for this compound.

Gossypol, a cell permeable polyphenole identified in cotton plants, inhibits noncompetitively the enzymatic activity of calcineurin but of none of the other Ser/Thr protein phosphatases. The inhibition of pNPP and $\mathrm{R}_{\mathrm{II}}$ phosphopeptide dephosphorylation is reversible and is independent of immunophilins or other matchmaker proteins. Gossypol inhibits the nuclear translocation of NFATc in activated T cells. The reported effect of gossypol on calcineurin-calmodulin interaction [103] cannot account for these specific effects, as gossypol only partially prevents the binding of calmodulin to calcineurin and just at very low concentrations of calmodulin. Gossypol shows immunosuppressive effects in mice [104] and inhibitory effects on growth, cell signalling and development in Dictyostelium cells. These effects are specific for calcineurin as they can be diminished by calcineurin overexpression [105]. However, gossypol has been reported to additionally inactivate other enzymes than calcineurin such as dehydrogenases [106], phospholipase A2 [107] and topoisomerase II [108].

Lie120, a thiazole derivative, inhibits the enzymatic activity of calcineurin but not the PPIase activity of FKBPs or cyclophilins. Dephosphorylation of pNPP and $\mathrm{R}_{\mathrm{II}}$ phosphopeptide is inhibited by Lie120 in cell-free assays. In neuronal cell lines it prevents the FK506-sensitive $\mathrm{H}_{2} \mathrm{O}_{2}$ triggered activation of JNK. However, Lie 120 is toxic at concentrations higher than $5 \mu \mathrm{M}[80]$.

PD 144795, a benzothiophene derivative, blocks the enzymatic activity of calcineurin in cell lysates. In Jurkat $T$ cells transfected with an HIV-1 LTR fragment, PD 144795 inhibits the calcineurin-dependent binding of p53 and $\mathrm{NF}-\kappa \mathrm{B}$ to the HIV promoter element. These inhibitory effects are abolished by overexpression of calcineurin [109]. 
Dibefurin, a fungal phenolic compound, inhibits the enzymatic activity of calcineurin against the small molecular substrate 4-methylumbelliferyl phosphate. Furthermore, it shows suppressive effects in both assays, mixed lymphocyte reaction (MLR) and lymphocyte cytotoxicity analysis [110].

Compounds inhibiting the enzymatic activity of calcineurin are supposed to block the dephosphorylation of all protein substrates. Therefore, only compounds targeting specific calcineurin-substrate interactions but not the general phosphatase activity of calcineurin might be able to dissect the action of calcineurin on different substrates. Recently, different efforts were made to identify such compounds, interfering specifically with calcineurin-NFATc interactions in $\mathrm{T}$ cells.

Dipyridamole, a drug clinically used for stroke treatment, is suggested to affect the interaction of NFATc with calcineurin, because it competes with fluorescence-labelled RCAN1-CIC peptide (see below) for binding to calcineurin. Dipyridamole does not interfere with the phosphatase activity of calcineurin on $\mathrm{R}_{\mathrm{II}}$ phosphopeptide in cell-free assays. It suppresses ionomycin-induced NFATc2 nuclear translocation in Jurkat $\mathrm{T}$ and $\mathrm{U}-2$ osteosarcoma cell lines, and blocks subsequently NFATc-dependent reporter gene and cytokine expression [111]. Dipyridamole inhibits TNF $\alpha$ production in activated PBMC [112].

NCI3, a pyrazolopyrimidine derivative, does not influence the enzymatic activity of calcineurin in cell-free systems. However, NCI3 inhibits NFATc dephosphorylation and nuclear translocation, IL-2 secretion and cell proliferation upon stimulation of Jurkat or primary human $\mathrm{T}$ cells. NFATc-dependent reporter gene expression is more sensitive to NCI3 than NF- $\mathrm{KB}$, whereas AP-1-dependent transcription is not influenced. These effects are diminished by calcineurin overexpression. An effect of NCI3 on the calcineurin-substrate interface is postulated as it partially displaces the VIVIT peptide, an oligopeptide derived from the PxIxIT-calcineurin binding motif of NFATc (see below) [113].

INCA compounds are a group of chemically unrelated substances selected in a screening for inhibition of NFATccalcineurin interaction. INCA-1, 2 and 6 bind covalently but reversibly to calcineurin at the residue Cys266. Subsequently, steric changes mask the binding site for NFATc and VIVIT peptide. INCA-2, but not INCA-6, inhibits the enzymatic activity of calcineurin. INCA- 6 inhibits the dephosphorylation of NFATc and its nuclear import in ionomycin-stimulated Cl.7W2 murine T cell line and, consequently, the expression of IFN $\gamma$ and TNF $\alpha$. However, general cytotoxicity has been reported for all INCA compounds, ruling out their use in primary cells $[114,115]$.

\section{Inhibitors not acting directly on the calcineurin molecule} Inhibitors of calcineurin-NFATc signalling may not only act on calcineurin itself, but also up- or downstream of the calcineurin-NFATc interaction or dephosphorylation processes. Among the possibilities are effects of compounds on calcium mobilization, on the nuclear translocation of NFATc or on NFATc-DNA-binding (Figure 2). Inhibitors acting downstream of calcineurin activation might be more specific to suppress just NFATc activation than CsA or FK506 complexes.

BTPs or 3,5-Bis(trifluoromethyl)pyrazoles are a batch of NFATc modulators with different modes of action $[116,117]$.

BTP1 and BTP3 (compounds 1 and 2 in Djuric et al.) are supposed to interfere with calcineurin-dependent NFATc activation, because calcineurin activity against $\mathrm{R}_{\mathrm{II}}$ phosphopeptide and phosphorylated Elk1 is not inhibited in enzyme assays and in cell lysates. BTP1 and BTP3 diminish activation-dependent NFATc dephosphorylation, its nuclear translocation in primary $\mathrm{T}$ cells and cell lines as well as subsequent cytokine production and cell proliferation. It is assumed that NF- $\mathrm{KB}$ or AP-1 activation are not affected by BTP1 and BTP3 [118].

BTP2 (compound 3 in Djuric et al., alternative name YM58483) dose-dependently enhances TRPM4, a Ca ${ }^{2+}$-activated nonselective cation channel. Thereby, BTP2 decreases CRAC-channel-dependent $\mathrm{Ca}^{2+}$ influx due to depolarization of lymphocyte cell membranes. Subsequently, the activation of calcineurin is diminished, leading to a reduced NFATc-driven promoter activity and IL-2 production in Jurkat T cells. AP-1-driven promoter activity is not influenced. BTP2 also inhibits the proliferation and $\mathrm{Ca}^{2+}$-dependent cytokine production in stimulated human CD4+ T cells [119-121] and the expression of IL-4 and IL-5 in an antigen-stimulated murine $\mathrm{T}_{\mathrm{H}} 2 \mathrm{~T}$ cell clone. In vivo studies show an inhibition of antigen-induced airway-inflammation [122], of donor anti-host cytotoxic $\mathrm{T}$ lymphocyte activity and IFN $\gamma$ production in graft versus host disease, and of delayed-type hypersensitivity response in mice [123]. Inhibition of $\mathrm{Ca}^{2+}$-dependent functional responses of human neutrophils and granulocyte-differentiated HL60 cell line was also observed [124]. However, it is unclear to which extent these observed effects are caused by inhibition of calcineurin, because other $\mathrm{Ca}^{2+}$-dependent processes are suppressed, too. In particular, the activation of the calmodulin-dependent kinases (CaMK) plays an important role in T cell activation and inflammatory responses.

BTP A-285222 (compound 19 in Djuric et al.) has immunosuppressive effects in an animal model but exhibits severe side effects, such as neurotoxicity. The molecular 
mode of action of BTP A-285222 is not known, nevertheless many effects on different cell types are observed. It was found that cytokine production of T cells is reduced by $80 \%$ in BTP A-285222-treated mice [125], that agonistinduced NFATc3-dependent IL-6 production is inhibited in myometrial arteries and that proliferation of isolated vascular smooth muscle cells is impaired $[126,127]$.

ST1959, a 3,5-diaryl-s-triazole derivative which is also named DL111-IT/contragestazol, inhibits $\mathrm{T}$ cell activation, proliferation and cytokine production by enhancing the nuclear export of NFATc2. NFATc2 de- and rephosphorylation are not influenced. NF-אB- and AP-1-dependent gene transcription are reported to be not affected [128]. The compound shows immunosuppressive effects in several animal models of autoimmune diseases, such as colitis and host versus graft disease $[129,130]$.

AM404, a product of the acetaminophen (paracetamol) catabolism [131], inhibits NFATc2-DNA binding and transcriptional activity in Jurkat $\mathrm{T}$ cells, but not in cell lysates. It is postulated that AM404 inhibits the nuclear translocation of dephosphorylated NFATc. AM404 does not inhibit $\mathrm{Ca}^{2+}$ influx, disturbs only slightly the dephosphorylation of NFATc2 in cells and does presumably not interfere with the signalling pathways leading to NF- $\mathrm{kB}$ or AP-1 activation. However, AM404 suppresses IL-2 and $\mathrm{TNF} \alpha$ transcription, $\mathrm{T}$ cell proliferation and cytokine release in Jurkat $\mathrm{T}$ cells after $\alpha \mathrm{CD} 3 / 28$ stimulation [132].

UR-1505 is a pentafluoropropoxy derivative of salicylic acid [133]. It blocks the binding of NFATc to DNA upon ionomycin stimulation but has no effect on the nuclear translocation of NFATc. Therefore, UR-1505 effects are not due to NFATc-export inhibition or enhanced re-phosphorylation. The activation of NF- $\mathrm{kB}$ and AP-1 seems to be not affected. UR-1505 inhibits $\alpha \mathrm{CD} 3 / \mathrm{CD} 28$-induced, but not JAK/STAT-induced T cell proliferation and IL-5 as well as IFN $\gamma$ expression. UR-1505 shows anti-inflammatory properties in rat colitis models [134]. Triflusal, another salicylic acid derivative, inhibits not only NFATcDNA complex formation, but additionally NF- $\kappa B$ activation [135].

Rocaglamide derivatives Roc- 1,2 and 3 inhibit the activation-induced NFATc1 translocation into the nucleus. It is supposed that elevated kinase activities of p38 MAPK and JNK by Roc-1, 2 and 3 cause an increased NFATc rephosphorylation. This inactivation of NFATc leads to a reduced expression of IL-2, IL-4, IFN $\gamma$ and TNF $\alpha$. The nuclear localization of c-Jun, a potential subunit of AP-1, is also inhibited. Surprisingly, only NFATc- but not AP1or NF-kB-dependent reporter gene transcription is suppressed by the inhibitors in the selected concentration range (up to $100 \mathrm{nM}$ ) [136].
Tropisetron, an antagonist of the serotonin receptor, inhibits NFATc-dependent signalling caused by overexpression of the constitutively active calcineurin construct $\Delta$ CaM-AI [137]. Therefore, a target at or downstream of calcineurin activity was suggested. Tropisetron inhibits the transcriptional activities of NFATc, NF- $\mathrm{BB}$ and AP-1 in PMA/ionomycin-, but not TNF $\alpha$-stimulated Jurkat T cells. Tropisetron suppresses the phosphorylation of p38 MAPK and JNK but not the phosphorylation of ERK 1 and 2. It inhibits IL-2 production in primary T cells upon SEB stimulation [138]. Tropisetron ameliorates acetic-acidinduced colitis in rats [139].

Venkatesh et al. selected 14 compounds in a screening of a library with 16,000 substances for inhibitors of GFPNFATc3 nuclear translocation in HeLa cells. Most of them interfered with calcium mobilization and therefore calcineurin activation [140].

WIN 53071 alters NFATc-DNA complex formation in intact cells but not in cell-free binding assays. It does not inhibit the enzymatic activity of calcineurin against $R_{\mathrm{II}}$ phosphopeptide. WIN 53071 inhibits $\mathrm{Ca}^{2+}$-dependent IL2 expression in primary human lymphocytes, MLR and NFATc-driven reporter gene expression [141].

Trifluoperazine binds to calmodulin and inhibits its interaction with calcineurin [142]. Therefore, trifluoperazine inhibits calcineurin activation and suppresses the dephosphorylation of $\mathrm{R}_{\mathrm{II}}$ phosphopeptide in cell lysates [143] and IL-2 expression of $\alpha$ CD3/PMA-activated Jurkat T cells. Due to its mode of action, also other calmodulindependent but calcineurin-independent processes are modulated, such as phosphatidylserine synthesis [144].

\section{Inhibitors with unknown mode of action}

Several compounds, belonging to different chemical classes, were found to inhibit NFATc-dependent gene expression and other NFATc-mediated cellular effects. However, the underlying molecular mechanisms of the compounds listed in this chapter were not elucidated in detail by the respective authors.

KRM-III inhibits NFATc-, but not NF-kB-dependent reporter gene expression in PMA/ionomycin stimulated Jurkat T cells. KRM-III diminishes the proliferation of TCR-stimulated murine T cells and MLR. Upon oral application to mice, KRM-III reduces the IL-2 levels in blood after $\alpha \mathrm{CD} 3$-injection, and diminishes delayed type hypersensitivity responses and MOG-induced experimental autoimmune encephalomyelitis [145].

Caffeic Acid Phenethyl Ester (CAPE), a phenolic compound derived from honey bee propolis, inhibits IL-2 promoter activity and cytokine synthesis, NF- $\mathrm{kB}$ binding 
to DNA in PMA-stimulated Jurkat cells (but not $\mathrm{I} \kappa \mathrm{B} \alpha$ degradation), NFATc dephosphorylation after PMA/ionomycin stimulation, and the DNA binding of a pGal4NFATc2(1-415) fusion protein in cells. CAPE inhibits not only the percentage of cells expressing the activation markers CD25, CD69, and ICAM-1 at the cell surface but also the relative intensity of fluorescence in the positive cell population [146]. It is a potent inhibitor of antigenand mitogen-induced T-cell proliferation, cytokine production [147], and NF- $\kappa \mathrm{B}$ activation [148]. The precise mode of action of CAPE remains unclear.

YM-53792 suppresses NFATc-, but not AP-1- and NF-кBdriven promoter activities and the formation of NFATcDNA complexes in stimulated Jurkat cells. YM-53792 inhibits IL-2 gene promoter activity and the expression of IL-2, IL-4 and IL-5 in stimulated human peripheral blood mononuclear cells. It was assumed that YM-53792 specifically inhibits the calcineurin-NFATc pathway, but the molecular mechanism is not elucidated [149].

Quinazolinediones and pyrrolopyrimidinediones, selected by screening of a compound library, inhibit NFATc-dependent reporter gene transcription in Jurkat cells [150]. No further examination of their mode of action has been reported. Recent data suggest that the inhibitory effect of quinazolinediones such as WIN 61058 [141] is independent of calcineurin but due to inhibition of the monocarboxylate transporter MCT1, which is crucial in the export of catabolic lactate from activated blastic T cells [151].

NFAT-68 and NFAT-133 are no proteins but in fact fungal aromatic compounds. They do not interfere with calcineurin phosphatase activity against 4-methylumbelliferyl phosphate, but inhibit NFATc-driven reporter gene transcription, MLR and lymphocyte toxicity [152].

Many traditional medical plants, parts of plants or specific preparations from them often have anti-inflammatory properties. To identify the responsible natural ingredients and to search for novel calcineurin-NFATc-pathway inhibitors, different libraries were recently screened for inhibitors of NFATc-dependent reporter gene expression. Unfortunately, most of the selected compounds were not further characterized concerning their mode of action and their effects on the inhibition of other transcription factors and pathways.

Punicalagin, isolated from the fruit of Punica granatum, inhibits NFATc nuclear translocation and DNA binding. It diminishes $\alpha \mathrm{CD} 3 / 28$-induced IL-2 production of CD4+ $4^{+}$ cells and shows slight suppression of MLR. Immunosuppressive effects of punicalagin were observed in a PMAinduced edema mouse model [153].
Imperatorin isolated from Oppopanax chironium(L.), a furanocumarin, inhibits both NFATc transcriptional and DNA-binding activities. It blocks the expression of the reporter gene luciferase controlled by NFATc- or IL-2dependent promoter region, but not the expression under control of an NF- $\mathrm{BB}$ - or AP-1-dependent promoter. Imperatorin suppresses the proliferation of SEB-stimulated $\mathrm{T}$ cells [154].

Quinolone alkaloids from the Evodia rutaecarpa fruit inhibit NFATc- and NF- $\mathrm{B}$-dependent reporter gene expression in Jurkat T cells. Several of these alkaloids suppress NFATc signalling stronger than NF- $\kappa$ B without affecting the viability of the Jurkat T cell line [155].

Several compounds, extracted from of Asian plants, inhibit NFATc-dependent reporter gene expression: phenolic constituents 2 and 3 of Desmos chinensis [156], gymnasterkoreayne $\mathbf{G}$, a polyacetylene isolated from the leaves of Gymnaster koraiensis [157], compound 1 from Ribes fasciculatum var. chinense [158], Impressic acid [159], lignans [160], and diterpenoids [161], contained in Acanthopanax koreanum root, oleanane triterpenoid compound 3, contained in the fruits of Liquidambar formosana, [162], as well as gomisin $\mathbf{N}$ and schisandrol $\mathbf{A}$, lignans from Schisandra chinensis [163].

\section{Inhibitory peptides and proteins from pathogens}

Protein domains from interaction partners of calcineurin are usually the point of origin to design inhibitory peptides. These specific peptides, targeting the binding of calcineurin to selected partners and substrates, might be more specific than CsA- or FK506-complexes (Table 2). They should help to delineate the interaction mechanisms of calcineurin interaction with other signalling partners. Additionally, modifications of these peptides such as fragment shortening and point mutations will support these efforts. However, often these peptides have low cell membrane permeability, even when they are synthesized with specific modifications such as leading peptide sequences containing oligo-arginines.

\section{Inhibitory peptides}

AID fragments, derived from the autoinhibitory domain of the calcineurin A subunit were the first examined inhibitory peptides for calcineurin. These peptides, containing the residues 424-521 ( IID $_{424-521}$ ), are potent inhibitors of the phosphatase activity by blocking the access of protein substrates to the catalytic centre of calcineurin [164]. A peptide spanning the residues 457-482 ( AID $_{457-482}$ ) of calcineurin represents the core inhibitory motif $[165,166]$. This peptide is already able to suppress the dephosphorylation of the $\mathrm{R}_{\mathrm{II}}$ phosphopeptide in phosphatase assays. However, additional autoinhibitory elements are present within the calcineurin region 420-457. Therefore, the pep- 
Table 2: Peptides and proteins inhibiting calcineurin-NFATc signalling

\begin{tabular}{|c|c|c|c|}
\hline Inhibitor peptide & Mode of action & $I C_{50} / K_{d} * / K_{i}^{* *}$ & References \\
\hline $\mathrm{CaN}_{457-482}$-AID & \multirow{2}{*}{ mask the active centre of $\mathrm{CaN}$} & $10 \mu \mathrm{M}^{\mathrm{a}}$ & Perrino BA 1999 [167] \\
\hline $\mathrm{CaN}_{424-521}-\mathrm{AID}$ & & $2.5 \mu \mathrm{M}^{\mathrm{a}}$ & Sagoo JK 1996 [164] \\
\hline mNFATc2 $2_{|06-12|}$ - SPRIEIT & \multirow{2}{*}{ block $\mathrm{CaN}-\mathrm{NFATc}$ interaction } & $12 \mu \mathrm{Mi}$ & Aramburu J 1998 [2I] \\
\hline VIVIT peptide & & $\begin{array}{l}0.5 \mu \mathrm{M}^{* \mathrm{k}} \\
<\mathrm{I} \mu \mathrm{M}^{\prime}\end{array}$ & $\begin{array}{l}\text { Roehrl MH } 2004[114] \\
\text { Aramburu J } 1999[171]\end{array}$ \\
\hline AKAP79 $_{330-357}$ & blocks CaN-NFATc interaction & $\mathrm{I} .5 \mu \mathrm{Ma}$ & Dell'Acqua ML 2002 [173] \\
\hline RCANI & \multirow{3}{*}{ block CaN-NFATc interaction } & $60 \mathrm{nM} * \mathrm{k}$ & Chan B 2005 [177] \\
\hline RCANI-4|4|-197 - exon7 & & $70 \mathrm{nM} M^{* k}$ & Chan B 2005 [177] \\
\hline RCANI-4 ${ }_{143-163}-$ CIC peptide & & $\mathrm{I} .25 \mu \mathrm{M}^{* \mathrm{k}}$ & Mulero MC 2009 [III] \\
\hline LxVPcl peptide & $\begin{array}{l}\text { blocks } \mathrm{CaN}-\mathrm{NFATc} \text { interaction and modulates enzymatic } \\
\text { activity of } \mathrm{CaN}\end{array}$ & $\sim 3 \mu \mathrm{M}^{\mathrm{a}}$ & Rodriguez A 2009 [24] \\
\hline RCANI-495-118-SP repeat peptide & masks the active centre of $\mathrm{CaN}$ & $91.5 \mu \mathrm{M}^{* * \mathrm{a}}$ & Vega RB 2002 [185] \\
\hline VacA & inhibits translocation of NFATc & N.D. & Gebert B 2003 [187] \\
\hline A238L & \multirow{2}{*}{ block CaN-NFATc interaction } & N.D. & Miskin JE 1998 [190] \\
\hline$A 238 L_{200-213}$ & & $0.6 \mu \mathrm{Mk}^{\mathrm{k}}$ & Miskin JE 2000 [194] \\
\hline
\end{tabular}

N.D.: not determined

Indicated methods for $I_{50} / K_{d} / K_{i}$ determination: a - phosphatase assay on $R_{\| l}$ Phosphopeptide; $b$ - phosphatase assay on pNPP; $c$ - NFAT dependent reporter gene expression; $d$ - IL-2 promoter dependent reporter gene expression; e - phosphatase assay on 4-methylumbelliferyl phosphate; $f$ displacement of VIVIT peptide; $g$ - IL-2 secretion assay; $h$ - EMSA for NFATc; $i$ - interference with CaN-NFATc binding assay; $k$ - binding assay to $\mathrm{CaN} ; \mathrm{I}$ - phosphatase assay on NFATc; $\mathrm{m}$ - cell proliferation assay

tides containing the extended AID region $\mathrm{AID}_{420-511}$ and AID $_{328-511}$ were three- to fourfold more potent to inhibit $\mathrm{R}_{\mathrm{II}}$ phosphopeptide dephosphorylation compared to the AID $_{457-482}$ peptide [167]. The $11 \mathrm{R}_{-A^{2}}{ }_{457-482}$ peptide, containing eleven arginine residues, is reported to be indeed cell-permeable for selected cell types. It inhibits apoptosis of excitatory neurons [168] and caerulein-induced zymogen activation in pancreatic acinar cells [169].

PxIxIT peptides are derived from the conserved calcineurin-docking motif PxIxIT found in NFATc and other proteins [170]. Peptides or protein fragments containing the PxIxIT element compete with NFATc for binding to calcineurin and impair thereby the binding and dephosphorylation of NFATc1, c2 and c4 in cell-free enzyme assays. In cells overexpressing PxIxIT peptides, the phosphatase activity of calcineurin and therefore the dephosphorylation of other substrates are not impaired [21$23,25]$.
The VIVIT 16 mer oligopeptide, designed by selective amino acid exchange, possesses 25 times higher efficiency to inhibit NFATc dephosphorylation compared to the original NFATc2 16 mer SPRIEIT peptide [171]. Overexpression of GFP-VIVIT fusion protein in Jurkat $\mathrm{T}$ cells inhibits NFATc- but not NF- $\mathrm{B}$-dependent reporter gene expression. Therefore, the VIVIT peptide is more selective than CsA and FK506 complexes which inhibit the activation of both transcription factors. 11R-VIVIT peptide is claimed to be cell-permeable in selected cell types [172], but there are contrary experimental experiences.

A peptide derived from the calcineurin-anchoring protein AKAP79 containing the PIAIIIT motif (AKAP79 $330-357$ ) binds to purified calcineurin. In contrast to other PxIxIT peptides, this motif inhibits the phosphatase activity against the $\mathrm{R}_{\mathrm{II}}$ phosphopeptide. Overexpression of AKAP79 ${ }_{330-357}$ in HEK293 cells antagonizes the interaction between AKAP79 and calcineurin [173]. 
The endogenous inhibitory protein CABIN1 contains a conserved PEITVT motif. A peptide spanning the residues 2078-2115 of rat CABIN1 binds to calcineurin [174], and human CABIN1 $1_{2143-2220}$ overexpression in Jurkat T cells inhibits NFATc dephosphorylation and NFAT-dependent luciferase expression [175]. Both fragments overlap at the KFPPEITVTPP sequence. Therefore, this motif is assumed to participate in the CABIN1-calcineurin interaction.

RCAN1, an endogenous modulator of calcineurin activity (also named DSCR1 or calcipressin1), is expressed in several splice variants which differ in their $\mathrm{N}$ termini but share an identical $\mathrm{C}$ terminus. In this review, the amino acid designation has been adapted from the splice variant RCAN1-4 [176], although several cited publications use the designation of the splice variant 1-1. RCAN1-exon7 (RCAN1-4 residues 141-197), containing the C-terminus, binds to full-length calcineurin and to a catalytic core fragment of calcineurin as well as full-length RCAN1. Both, RCAN1-exon7 and full-length RCAN1, inhibit competitively the dephosphorylation of pNPP in enzyme assays and the calcineurin-mediated nuclear translocation of NFATc3 in the BHK cell line after their overexpression [177]. Initially, the PKIIQT motif in this region (RCAN1$4_{181-186}$ ) was considered to mimic the NFATc PxIxIT motif and to inhibit NFATc-calcineurin interaction, but a peptide spanning the residues 178-191 did not compete with VIVIT peptide for binding to calcineurin. Recent experiments revealed that the RCAN1-4 ${ }_{136-163}$ fragment contains a region named calcineurin-inhibitor calcipressin 1 (CIC) motif, which is displaced from calcineurin by the VIVIT peptide [178]. The RCAN1-4 ${ }_{143-163}$ CIC fragment binds to calcineurin A with high affinity, competes with the binding of VIVIT peptide, and inhibits NFATc2 nuclear translocation as well as NFATc-dependent reporter gene expression in transfected COS-7 cells. Importantly, this fragment does not interfere with the phosphatase activity of calcineurin towards $\mathrm{R}_{\mathrm{II}}$ phosphopeptide and homologous regions are found in the related proteins RCAN2 (residues 147-167) and RCAN3 (residues 183-203) [111]. This fragment contains the "true" PxIxIT motif of RCANs - PSVVVH, which binds to the same hydrophobic pocket of calcineurin as the VIVIT peptide. Therefore, the PSVVVH peptide (RCAN1-4 149-166 ) competes with the regulatory region of NFATC2 or GST-CABIN1 for binding to calcineurin [179].

A peptide derived from the C-terminus of the yeast RCAN homologue $\operatorname{Rcn} 2\left(\operatorname{Rcn} 2_{252-265}\right)$, containing the PSITVN motif, is able to compete with the VIVIT peptide for binding to human calcineurin, too. Consequently, deletion of this motif in Rcn 2 abolishes its inhibition of calcineurin signalling in yeast [180].

The African Swine Fever Virus protein A238L contains a similar motif the PKIIITG motif (see below).
LxVP peptides are derived from the conserved calcineurin-docking NFATc motif LxVP and compete with NFATc for the binding to activated calcineurin. The NFATc isoforms differ in the affinity of their LxVP motifs towards calcineurin [181].

Pep3 is derived from the CNBR2 of NFATc3 (residues 321-406 of murine NFATc3). This 16-amino acid oligopeptide (mNFATc $3_{385-400}$ ) contains the LxVP motif, binds to purified and cellular calcineurin and competes with GST-CNBR2 for binding to calcineurin. Retroviral overexpression of Flag-Pep3 in the murine D10G4.1 $\mathrm{T}_{\mathrm{H}} 2$ cell line impaired the expression of IL-5, IL- 6 and IL-13 and the nuclear translocation of NFATc3 after PMA/calcium ionophore stimulation. NFATc3, but not NFATc2 and NF-KB activation is affected by Pep3 [182].

The LxVPc1 peptide, spanning the 15 amino acids of human NFATc1 371-385, disrupts calcineurin-NFATc1 and $\mathrm{c} 2$ binding. GST-LxVPc1 binds to calcineurin more efficiently than any of the PxIxIT motifs of NFATc1 to c4. The GST-LxVPc2 fusion peptide from NFATc2 was unable to bind to calcineurin under the same conditions. The LxVPc1 peptide inhibits calcineurin phosphatase activity on the $\mathrm{R}_{\mathrm{II}}$ phosphopeptide and increases the phosphatase activity on pNPP. Overexpression of GFP-LxVPc1 fusion protein in HeLa cells inhibits NFATc2 dephosphorylation and nuclear translocation upon ionophore treatment; in Jurkat T cells it inhibits NFATc2 dephosphorylation and the expression of luciferase under control of the IL-2 or RCAN1-4 promoter upon PMA/ionophore stimulation $[23,24]$.

Protein fragments based on other motifs were derived from CABIN1 and RCAN1. The protein fragment CABIN1 ${ }_{700-901}$ inhibits the dephosphorylation of the $\mathrm{R}_{\mathrm{II}}$ phosphopeptide by calcineurin in a noncompetitive manner. Overexpression of CABIN $1_{700-901}$ in HEK293 cells coexpressing constitutively active calcineurin inhibits the dephosphorylation of NFATc2, its nuclear translocation and luciferase reporter gene expression under NFAT control. Overexpression of this fragment in Jurkat T cells suppresses the expression of luciferase controlled by the IL-2 promoter upon PMA/ionomycin stimulation [183].

RCAN 1 and 2 contain a SP repeat motif binding to the catalytic centre of calcineurin. The SP repeat peptide ( RCAN1-4 ${ }_{95-118}$ ), which can be phosphorylated by MAPK and GSK-3, simulates a substrate for calcineurin and thereby inhibits calcineurin activity against $R_{I I}$ phosphopeptide in a competitive manner in cell-free assays. This inhibitory effect is independent of the phosphorylation status of the peptide. However, overexpressed RCAN1 fragments containing only the SP repeat domain do not suppress calcineurin-NFATc signalling in cells $[184,185]$. A peptide containing the CIC motif and the C- 
terminal 30 amino acids of RCAN1 blocks dephosphorylation of the $\mathrm{R}_{\mathrm{II}}$ phosphopeptide by calcineurin, but neither the CIC containing peptide nor the $\mathrm{C}$-terminus alone. It is suggested, that the C-terminal inhibitory motifs have to be in close proximity to calcineurin via binding of the CIC motif [179].

\section{Pathogen proteins}

Calcineurin represents a crucial hub of $\mathrm{T}$ cell receptordependent signalling and controls the $\mathrm{T}$ cell activation mainly via NFATc dephosphorylation. Targeting this mechanism would enable pathogens to evade the host immune responses. Therefore, several viruses and bacteria have developed proteins inhibiting calcineurin-NFATcdependent signalling. Characterizing these proteins might help to understand host defence mechanisms.

VacA is a protein from $H$. pylori, which inhibits the nuclear translocation of NFATc. In addition, VacA blocks ionomycin-induced increase of intracellular $\mathrm{Ca}^{2+}$ level, and the activation of the MKK3/6-p38 MAPK pathway. These data suggest multiple modes of VacA action, not all of them seem to be calcineurin-NFATc-dependent [186]. However, VacA inhibits T cell activation, proliferation and IL-2 secretion in Jurkat cell lines and primary human $\mathrm{CD} 44^{+} \mathrm{T}$ cells $[187,188]$. VacA is imported into the T cell via the receptors CD18 and LFA-1 [189]. The expression of these cell surface proteins varies in different cell types, resulting in a different magnitude of inhibitory effects.

A238L, a protein of the african swine fever virus, seems to have different functions: first, to bind to calcineurin and inhibit its phosphatase activity and thus calcineurindependent pathways [190]; second, to suppress the acetylation and transcriptional activation of the transcription factors NFATc2, NF- $\mathrm{KB}$, and c-Jun by inhibition of transactivation of the transcriptional co-activator CREB binding protein/p300 by PKC $\theta$ in stimulated human $\mathrm{T}$ cells [191]; and third, to inhibit the activation of JNK [192]. Overexpression of A238L reduces calcineurin phosphatase activity against $\mathrm{R}_{\mathrm{II}}$ phosphopeptide in cell lysates and diminishes NFATc-dependent reporter gene expression in transfected porcine RS-2 kidney cells [190]. It is speculated that A238L only inhibits the dephosphorylation of such NFATc residues which might be crucial for its transactivation function but has no effect on the dephosphorylation of the other residues required for nuclear translocation or DNA binding [193]. Effects of A238L on NFATc-dependent gene transcription are abolished by cooverexpression of the constitutively active calcineurin construct $\triangle \mathrm{CaM}$-AI or NFATc2 in Jurkat T cells [193]. Interestingly, A238L binds also to CypA, but this interaction seems to have no effect on A238L-calcineurin interaction [190].
The fragment $\mathbf{A 2 3 8}_{157-238}$ contains a PxIxIT site (here: PKIIITG) and binds to calcineurin with high affinity. The 14 mer oligopeptide derived from this fragment $\mathbf{A} 238 \mathbf{L}_{\mathbf{2 0 0}}$ ${ }_{213}$ binds to calcineurin even with a faster rate than the SPRIEIT peptide of porcine NFATc1 [194].

\section{Commentary Clinical application}

CsA and FK506 as well as some of their derivatives have become indispensible drugs to prevent transplant rejection and to treat dermatologic and autoimmune disorders. However, these drugs have a narrow therapeutic window. To reduce their adverse side effects different approaches were tested and some of them are still under investigation.

One strategy is to reduce the concentration of CsA and FK506, respectively, by combined application together with other immunosuppressive drugs having different modes of action, such as mycophenolate, rapamycin or monoclonal antibodies (e.g. Alemtuzumab). Another approach, especially in atopic dermatitis is to diminish systemic effects of the drugs by topical application of derivatives with enhanced lipophilic properties, such as pimecrolimus. A third approach is to apply CsA in low doses, thus taking advantage not only of its immunosuppressive, but also of its immunomodulatory properties [39].

Recently, some drugs originally introduced for applications other than inflammation turned out to act as inhibitors of calcineurin/NFATc activation. Among them are barbiturates, tropisetron and the acetaminophen/paracetamol catabolite AM404.

\section{Application in basic research}

Small molecular inhibitors and inhibitory peptides are valuable tools for a functional "knock-down" of cellular components to study the impact of different proteins, processes and pathways on specific cellular functions. Ideal inhibitors have to be monospecific, cell permeable and non-toxic. Most of the novel inhibitors, however, are not as well characterized as the "classical" inhibitors CsA and FK506.

Here we recommend the application of several inhibitors in basic research based on the intended investigations (Figure 2).

Inhibition of different Ser/Thr phosphatase activities Norcantharidin inhibits PP1, PP2A and calcineurin with comparable efficacy. Okadaic acid or calyculin A can be used to discriminate between calcineurin and the other main Ser/Thr protein phosphatases when applied in the nanomolar concentration range. Under this condition 
they inhibit PP1 and PP2A, which account for more than $90 \%$ of the cellular Ser/Thr phosphatase activity, and additionally PP4, PP5 and PP6, but they fail to inhibit calcineurin.

Inhibition of calcineurin phosphatase activity without modulation of PPlases activities

Gossypol and kaempferol are useful to inhibit the phosphatase activity of calcineurin not only in enzymatic assays but also in primary cells due to their low cytotoxicity. They inhibit calcineurin without the need for a matchmaker protein. Both compounds, however, additionally inhibit several other cellular enzymes. Inhibitors of calcium signalling, e.g. BTP2 and trifluoperazine, suppress the activation of calcineurin but they also act on other $\mathrm{Ca}^{2+}$ - or calmodulin-dependent processes, such as $\mathrm{Ca}^{2+}$ dependent PKCs or CaMKI/II. Peptides derived from the auto-inhibitory domain of calcineurin inhibit the phosphatase activity with high specificity, but their application is limited due to their reduced cell permeability.

\section{Inhibition of NFATc dephosphorylation}

NCI3 and dipyridamole are cell permeable compounds which inhibit NFATc dephosphorylation in cells without inhibition of the phosphatase activity of calcineurin in enzymatic assays. INCA-6 inhibits NFATc dephosphorylation and can be used in cell-free systems but is not recommended in primary cells due to its cytotoxicity. VIVIT peptide competes with NFATc for binding to calcineurin and is appropriate to inhibit NFATc dephosphorylation in cell-free assays.

\section{Inhibition of NFATc-dependent gene transcription}

BTP1, ST1959 and Roc-1 inhibit NFATc-dependent gene transcription presumably downstream of the calcineurinNFATc interaction. These compounds are supposed to have no or low inhibitory effects on NF- $\mathrm{B}$ or AP-1 activation.

Several other novel inhibitors of NFATc-dependent gene transcription have been isolated or synthesized. However, most of them have not been characterized so far and their molecular mode of action remains to be elucidated. Therefore, these compounds cannot be recommended as tools to dissect and define mechanisms of calcineurin action in the complex signalling network of cells.

\section{Conclusion}

In summary, CsA and FK506 are firmly established in the clinical routine. Several approaches are applied or under investigation to limit their side effects. In basic research, several more specific, although less well characterized, inhibitors of the calcineurin-NFATc axis can be utilized as alternatives. So far, their widespread application is hindered by a limited commercial availability.

\section{List of abbreviations used}

AID: autoinhibitory domain of calcineurin; AP-1: activator protein 1; CsA: cyclosporin A; CypA: cyclophilin A; FKBP: FK506-binding protein; $\mathrm{CaN}$ : calcineurin; CaM: calmodulin; GFP: green fluorescent protein; MAPK: mitogen activated protein kinase; MLR: mixed lymphocyte reaction; NFATc: nuclear factor of activated $\mathrm{T}$ cells, cytosolic; NF- $\kappa \mathrm{B}$ : nuclear factor $\kappa \mathrm{B}$; PMA: phorbol12-myristate-13-acetate; pNPP: para-nitrophenyl phosphate; PP: protein phosphatase; PPIase: peptidyl-prolyl cis-trans isomerase; TCR: T cell receptor; TGF- $\beta$ : transforming growth factor $\beta$

\section{Competing interests}

The authors declare that they have no competing interests.

\section{Authors' contributions}

Both authors contributed to the writing of this manuscript and approved the final manuscript.

\section{Additional material}

\section{Additional file 1}

IUPAC names or chemical structures of low molecular weight inhibitors of $\mathrm{CaN}-\mathrm{NFATc}$ signalling. The table summarizes the IUPAC names or structural formulas of the low molecular weight inhibitors of $\mathrm{CaN}$ NFATc signalling reviewed in this article.

Click here for file

[http://www.biomedcentral.com/content/supplementary/1478811X-7-25-S1.DOC]

\section{Acknowledgements}

We thank Peter Liman and Claudia Brandt for helpful comments about the application of immunosuppressants in clinical routine. The work was supported by the German Federal Ministry of Education and Research (BMBF) within the FORSYS Partner Initiative Berlin and by the Deutsche Forschungsgemeinschaft within the SFB52.

\section{References}

I. Klee CB, Krinks MH: Purification of cyclic 3',5'-nucleotide phosphodiesterase inhibitory protein by affinity chromatography on activator protein coupled to Sepharose. Biochemistry 1978 , 17:120-126.

2. Crabtree GR, Olson EN: NFAT signaling: choreographing the social lives of cells. Cell 2002, I 09(Suppl):S67-79.

3. Klee $C B$, Ren $H$, Wang $X$ : Regulation of the calmodulin-stimulated protein phosphatase, calcineurin. J Biol Chem I998, 273: 13367-13370.

4. Liu JO: Endogenous protein inhibitors of calcineurin. Biochem Biophys Res Commun 2003, 3 I I : I I03-I I09.

5. Liu JO: Calmodulin-dependent phosphatase, kinases, and transcriptional corepressors involved in $\mathbf{T}$-cell activation. Immunol Rev 2009, 228:184-198.

6. Morioka M, Hamada J, Ushio Y, Miyamoto E: Potential role of calcineurin for brain ischemia and traumatic injury. Prog Neurobiol I999, 58: I-30.

7. Rao A, Luo C, Hogan PG: Transcription factors of the NFAT family: regulation and function. Annu Rev Immunol 1997, I 5:707-747. 
8. Serfling E, Berberich-Siebelt F, Churpilo S, Jankevics E, Klein-Hessling $S$, Twardzik T, Avots A: The role of NF-AT transcription factors in $\mathbf{T}$ cell activation and differentiation. Biochim Biophys Acta 2000, 1498: I- 18.

9. Hogan PG, Chen L, Nardone J, Rao A: Transcriptional regulation by calcium, calcineurin, and NFAT. Genes Dev 2003, I 7:2205-2232

10. Macian F: NFAT proteins: key regulators of T-cell development and function. Nat Rev Immunol 2005, 5:472-484.

II. Yang J, Rothermel B, Vega RB, Frey N, McKinsey TA, Olson EN, Bassel-Duby R, Williams RS: Independent signals control expression of the calcineurin inhibitory proteins MCIPI and MCIP2 in striated muscles. Circ Res 2000, 87:E6I-68.

12. Batiuk TD, Halloran PF: The downstream consequences of calcineurin inhibition. Transplant Proc 1997, 29:1239-1240.

13. Graef IA, Chen F, Chen L, Kuo A, Crabtree GR: Signals transduced by $\mathrm{Ca}(2+) / c a l c i n e u r i n$ and NFATc3/c4 pattern the developing vasculature. Cell 200I, I05:863-875.

14. Bueno OF, Brandt EB, Rothenberg ME, Molkentin JD: Defective T cell development and function in calcineurin $A$ beta-deficient mice. Proc Natl Acad Sci USA 2002, 99:9398-9403.

15. Okamura H, Aramburu J, Garcia-Rodriguez C, Viola JP, Raghavan A, Tahiliani M, Zhang X, Qin J, Hogan PG, Rao A: Concerted dephosphorylation of the transcription factor NFATI induces a conformational switch that regulates transcriptional activity. Mol Cell 2000, 6:539-550.

16. Luo C, Shaw KT, Raghavan A, Aramburu J, Garcia-Cozar F, Perrino BA, Hogan PG, Rao A: Interaction of calcineurin with a domain of the transcription factor NFATI that controls nuclear import. Proc Natl Acad Sci USA 1996, 93:8907-8912.

17. Zhu J, Shibasaki F, Price R, Guillemot JC, Yano T, Dotsch V, Wagner G, Ferrara P, McKeon F: Intramolecular masking of nuclear import signal on NF-AT4 by casein kinase I and MEKKI. Cell |998, 93:85|-86|.

18. Beals CR, Sheridan CM, Turck CW, Gardner P, Crabtree GR: Nuclear export of NF-ATc enhanced by glycogen synthase kinase-3. Science 1997, 275:1930-1934.

19. Okamura H, Garcia-Rodriguez C, Martinson H, Qin J, Virshup DM, Rao A: A conserved docking motif for CKI binding controls the nuclear localization of NFATI. Mol Cell Biol 2004 24:4|84-4I95

20. Liu J, Masuda ES, Tsuruta L, Arai N, Arai K: Two independent calcineurin-binding regions in the $\mathbf{N}$-terminal domain of murine NF-ATXI recruit calcineurin to murine NF-ATxI. J Immunol |999, 162:4755-4761.

21. Aramburu J, Garcia-Cozar F, Raghavan A, Okamura H, Rao A, Hogan PG: Selective inhibition of NFAT activation by a peptide spanning the calcineurin targeting site of NFAT. Mol Cell 1998, I:627-637.

22. Garcia-Cozar FJ, Okamura H, Aramburu JF, Shaw KT, Pelletier L, Showalter R, Villafranca E, Rao A: Two-site interaction of nuclear factor of activated T cells with activated calcineurin. J Biol Chem 1998, 273:23877-23883.

23. Martinez-Martinez S, Rodriguez A, Lopez-Maderuelo MD, OrtegaPerez I, Vazquez J, Redondo JM: Blockade of NFAT activation by the second calcineurin binding site. I Biol Chem 2006, 28 I:6227-6235

24. Rodriguez A, Roy J, Martinez-Martinez S, Lopez-Maderuelo MD, Nino-Moreno P, Orti L, Pantoja-Uceda D, Pineda-Lucena A, Cyert MS, Redondo JM: A conserved docking surface on calcineurin mediates interaction with substrates and immunosuppressants. Mol Cell 2009, 33:616-626.

25. Li H, Zhang L, Rao A, Harrison SC, Hogan PG: Structure of calcineurin in complex with PVIVIT peptide: portrait of a lowaffinity signalling interaction. J Mol Biol 2007, 369: I 296-1306.

26. Roy J, Li H, Hogan PG, Cyert MS: A conserved docking site modulates substrate affinity for calcineurin, signaling output, and in vivo function. Mol Cell 2007, 25:889-90I.

27. Frantz B, Nordby EC, Bren G, Steffan N, Paya CV, Kincaid RL, Tocci MJ, O'Keefe SJ, O'Neill EA: Calcineurin acts in synergy with PMA to inactivate I kappa B/MAD3, an inhibitor of NF-kappa B. Embo J 1994, 13:861-870.

28. Sugimoto $T$, Stewart S, Guan KL: The calcium/calmodulindependent protein phosphatase calcineurin is the major ElkI phosphatase. J Biol Chem 1997, 272:294|5-294|8.
29. Dolmetsch RE, Xu K, Lewis RS: Calcium oscillations increase the efficiency and specificity of gene expression. Nature 1998, 392:933-936.

30. Alzuherri $\mathrm{H}$, Chang $\mathrm{KC}$ : Calcineurin activates NF-kappaB in skeletal muscle C2CI 2 cells. Cell Signal 2003, I 5:47I-478.

31. Valdes JA, Hidalgo J, Galaz JL, Puentes N, Silva M, Jaimovich E, Carrasco MA: NF-kappaB activation by depolarization of skeletal muscle cells depends on ryanodine and IP3 receptor-mediated calcium signals. Am J Physiol Cell Physiol 2007. 292:C1960-1970.

32. Guo L, Urban JF, Zhu J, Paul WE: Elevating calcium in Th2 cells activates multiple pathways to induce IL-4 transcription and mRNA stabilization. J Immunol 2008, I 8 I:3984-3993.

33. Liu Q, Busby JC, Molkentin JD: Interaction between TAKITABI-TAB2 and RCANI-calcineurin defines a signalling nodal control point. Nat Cell Biol 2009, I I:I54-16I.

34. Ninomiya-Tsuji J, Kishimoto K, Hiyama A, Inoue J, Cao Z, Matsumoto $\mathrm{K}$ : The kinase TAKI can activate the NIK-I kappaB as well as the MAP kinase cascade in the IL-I signalling pathway. Nature 1999, 398:252-256.

35. Pearl JP, Parris J, Hale DA, Hoffmann SC, Bernstein WB, McCoy KL, Swanson SJ, Mannon RB, Roederer M, Kirk AD: Immunocompetent T-cells with a memory-like phenotype are the dominant cell type following antibody-mediated T-cell depletion. $\mathrm{Am} J$ Transplant 2005, 5:465-474.

36. Jones $\mathrm{DL}$, Sacks $\mathrm{SH}$, Wong $\mathrm{W}$ : Controlling the generation and function of human CD8+ memory T cells in vitro with immunosuppressants. Transplantation 2006, 82:|352-|36|.

37. Taylor AL, Watson CJ, Bradley JA: Immunosuppressive agents in solid organ transplantation: Mechanisms of action and therapeutic efficacy. Crit Rev Oncol Hematol 2005, 56:23-46.

38. El-Batawy MM, Bosseila MA, Mashaly HM, Hafez VS: Topical calcineurin inhibitors in atopic dermatitis: a systematic review and meta-analysis. J Dermatol Sci 2009, 54:76-87.

39. Brandt C, Pavlovic V, Radbruch A, Worm M, Baumgrass R: Lowdose cyclosporine $A$ therapy increases the regulatory $T$ cell population in patients with atopic dermatitis. Allergy 2009, 64:1588-1596.

40. Rusnak F, Mertz P: Calcineurin: form and function. Physiol Rev 2000, 80: |483-|52|.

4I. Sugiura R, Sio SO, Shuntoh H, Kuno T: Molecular genetic analysis of the calcineurin signaling pathways. Cell Mol Life Sci 200I, 58:278-288.

42. Borel JF, Feurer C, Gubler HU, Stahelin H: Biological effects of cyclosporin A: a new antilymphocytic agent. Agents Actions 1976, 6:468-475

43. Calne RY, Rolles K, White DJ, Thiru S, Evans DB, McMaster P, Dunn DC, Craddock GN, Henderson RG, Aziz S, Lewis P: Cyclosporin A initially as the only immunosuppressant in $\mathbf{3 4}$ recipients of cadaveric organs: 32 kidneys, 2 pancreases, and 2 livers. Lancet 1979, 2:1033-1036.

44. Starzl TE, Weil R 3rd, Iwatsuki S, Klintmalm G, Schroter GP, Koep LJ, Iwaki Y, Terasaki PI, Porter KA: The use of cyclosporin A and prednisone in cadaver kidney transplantation. Surg Gynecol Obstet 1980, I 51:17-26.

45. Kino T, Hatanaka $\mathrm{H}$, Hashimoto $M$, Nishiyama M, Goto T, Okuhara M, Kohsaka M, Aoki H, Imanaka H: FK-506, a novel immunosuppressant isolated from a Streptomyces. I. Fermentation, isolation, and physico-chemical and biological characteristics. Antibiot (Tokyo) 1987, 40:1249-1255.

46. Starzl TE, Todo S, Fung J, Demetris AJ, Venkataramman R, Jain A: FK 506 for liver, kidney, and pancreas transplantation. Lancet 1989, 2:1000-1004.

47. Liu J, Farmer JD Jr, Lane WS, Friedman J, Weissman I, Schreiber SL: Calcineurin is a common target of cyclophilin-cyclosporin $A$ and FKBP-FK506 complexes. Cell 1991, 66:807-8I5.

48. Schreiber SL, Crabtree GR. The mechanism of action of cyclosporin A and FK506. Immunol Today 1992, I3: I 36-I42.

49. Barik S: Immunophilins: for the love of proteins. Cell Mol Life Sci 2006, 63:2889-2900.

50. Kang CB, Hong Y, Dhe-Paganon S, Yoon HS: FKBP family proteins: immunophilins with versatile biological functions. Neurosignals 2008, 16:318-325.

51. Griffith JP, Kim JL, Kim EE, Sintchak MD, Thomson JA, Fitzgibbon MJ, Fleming MA, Caron PR, Hsiao K, Navia MA: X-ray structure of cal- 
cineurin inhibited by the immunophilin-immunosuppressant FKBP I 2-FK506 complex. Cell 1995, 82:507-522.

52. Kissinger CR, Parge HE, Knighton DR, Lewis CT, Pelletier LA, Tempczyk A, Kalish VJ, Tucker KD, Showalter RE, Moomaw EW, et al.: Crystal structures of human calcineurin and the human FKBPI2-FK506-calcineurin complex. Nature 1995 , 378:64I-644.

53. Huai Q, Kim HY, Liu Y, Zhao Y, Mondragon A, Liu JO, Ke H: Crystal structure of calcineurin-cyclophilin-cyclosporin shows common but distinct recognition of immunophilin-drug complexes. Proc Natl Acad Sci USA 2002, 99: I 2037-I 2042.

54. Jin L, Harrison SC: Crystal structure of human calcineurin complexed with cyclosporin A and human cyclophilin. Proc Natl Acad Sci USA 2002, 99: 13522-13526.

55. Swanson SK, Born T, Zydowsky LD, Cho H, Chang HY, Walsh CT, Rusnak F: Cyclosporin-mediated inhibition of bovine calcineurin by cyclophilins A and B. Proc Natl Acad Sci USA 1992 89:374I-3745.

56. Yin M, Ochs RS: Mechanism for the paradoxical inhibition and stimulation of calcineurin by the immunosuppresive drug tacrolimus (FK506). Arch Biochem Biophys 2003, 41 9:207-2I3.

57. Handschumacher RE, Harding MW, Rice J, Drugge RJ, Speicher DW: Cyclophilin: a specific cytosolic binding protein for cyclosporin A. Science 1984, 226:544-547.

58. Siekierka JJ, Hung SH, Poe M, Lin CS, Sigal NH: A cytosolic binding protein for the immunosuppressant FK506 has peptidyl-proIyl isomerase activity but is distinct from cyclophilin. Nature 1989, 341:755-757.

59. Harding MW, Galat A, Uehling DE, Schreiber SL: A receptor for the immunosuppressant FK506 is a cis-trans peptidyl-prolyl isomerase. Nature 1989, 341:758-760.

60. Kalli K, Huntoon C, Bell M, McKean DJ: Mechanism responsible for T-cell antigen receptor- and CD28- or interleukin I (ILI) receptor-initiated regulation of IL-2 gene expression by NF-kappaB. Mol Cell Biol 1998, I8:3|40-3|48.

61. Aoki $Y$, Kao PN: Erythromycin inhibits transcriptional activation of NF-kappaB, but not NFAT, through calcineurin-independent signaling in T cells. Antimicrob Agents Chemother 1999, 43:2678-2684

62. Steffan NM, Bren GD, Frantz B, Tocci MJ, O'Neill EA, Paya CV: Regulation of IkB alpha phosphorylation by PKC- and $\mathrm{Ca}(2+)$ dependent signal transduction pathways. I Immunol 1995, | 55:4685-469|.

63. Oetjen E, Thoms KM, Laufer Y, Pape D, Blume R, Li P, Knepel W: The immunosuppressive drugs cyclosporin $A$ and tacrolimus inhibit membrane depolarization-induced CREB transcriptional activity at the coactivator level. Br J Pharmacol 2005, 144:982-993.

64. Marienfeld R, Neumann M, Chuvpilo S, Escher C, Kneitz B, Avots A, Schimpl A, Serfling E: Cyclosporin A interferes with the inducible degradation of NF-kappa B inhibitors, but not with the processing of p I05/NF-kappa B I in T cells. Eur J Immunol I997, 27:1601-1609.

65. Meyer S, Kohler NG, Joly A: Cyclosporine $\mathbf{A}$ is an uncompetitive inhibitor of proteasome activity and prevents NF-kappaB activation. FEBS Lett 1997, 413:354-358.

66. Nickel P, Presber F, Bold G, Biti D, Schonemann C, Tullius SG, Volk HD, Reinke P: Enzyme-linked immunosorbent spot assay for donor-reactive interferon-gamma-producing cells identifies T-cell presensitization and correlates with graft function at 6 and 12 months in renal-transplant recipients. Transplantation 2004, 78:1640-1646.

67. Naesens M, Kuypers DR, Sarwal M: Calcineurin inhibitor nephrotoxicity. Clin J Am Soc Nephrol 2009, 4:48I-508.

68. Kiani A, Rao A, Aramburu J: Manipulating immune responses with immunosuppressive agents that target NFAT. Immunity 2000, I2:359-372

69. Zhang Y, Baumgrass R, Schutkowski M, Fischer G: Branches on the alpha-C atom of cyclosporin $A$ residue 3 result in direct calcineurin inhibition and rapid cyclophilin 18 binding. Chembiochem 2004, 5:1006-1009.

70. Durette PL, Boger J, Dumont F, Firestone R, Frankshun RA, Koprak SL, Lin CS, Melino MR, Pessolano AA, Pisano J, et al.: A study of the correlation between cyclophilin binding and in vitro immunosuppressive activity of cyclosporine $A$ and analogues. Transplant Proc 1988, 20:5I-57.
7I. Sigal NH, Dumont F, Durette P, Siekierka J], Peterson L, Rich DH, Dunlap BE, Staruch MJ, Melino MR, Koprak SL, et al.: Is cyclophilin involved in the immunosuppressive and nephrotoxic mechanism of action of cyclosporin A? J Exp Med 1991, 173:619-628.

72. Nelson PA, Akselband Y, Kawamura A, Su M, Tung RD, Rich DH, Kishore V, Rosborough SL, DeCenzo MT, Livingston DJ, et al: Immunosuppressive activity of [MeBm2t] I-, D-diaminobutyryl-8-, and D-diaminopropyl-8-cyclosporin analogues correlates with inhibition of calcineurin phosphatase activity. Immunol 1993, I50:2139-2|47.

73. Baumgrass R, Zhang Y, Erdmann F, Thiel A, Weiwad M, Radbruch A, Fischer G: Substitution in position 3 of cyclosporin A abolishes the cyclophilin-mediated gain-of-function mechanism but not immunosuppression. J Biol Chem 2004, 279:2470-2479.

74. Aebi JD, Deyo DT, Sun CQ, Guillaume D, Dunlap B, Rich DH: Synthesis, conformation, and immunosuppressive activities of three analogues of cyclosporin A modified in the I-position. J Med Chem 1990, 33:999-1009.

75. Aspeslet L, Freitag D, Trepanier D, Abel M, Naicker S, Kneteman N, Foster R, Yatscoff R: ISA(TX)247: a novel calcineurin inhibitor. Transplant Proc 200I, 33:1048-105I.

76. Birsan T, Dambrin C, Freitag DG, Yatscoff RW, Morris RE: The novel calcineurin inhibitor ISA247: a more potent immunosuppressant than cyclosporine in vitro. Transpl Int 2005, I7:767-77|

77. Maksymowych WP, Jhangri GS, Aspeslet L, Abel MD, Trepanier D, Naicker S, Freitag DG, Cooper BL, Foster RT, Yatscoff RW: Amelioration of accelerated collagen induced arthritis by a novel calcineurin inhibitor, ISA(TX)247. J Rheumatol 2002, 29:1646-1652.

78. Naidoo P, Rambiritch V: Voclosporin (ISA247) for plaque psoriasis. Lancet 2008, 372:888-889. author reply 889 .

79. Dumont FJ, Staruch MJ, Koprak SL, Siekierka JJ, Lin CS, Harrison R, Sewell T, Kindt VM, Beattie TR, Wyvratt M, et al: The immunosuppressive and toxic effects of FK-506 are mechanistically related: pharmacology of a novel antagonist of FK-506 and rapamycin. J Exp Med 1992, I76:75I-760.

80. Klettner A, Baumgrass R, Zhang Y, Fischer G, Burger E, Herdegen T, Mielke $\mathrm{K}$ : The neuroprotective actions of FK 506 binding protein ligands: neuronal survival is triggered by de novo RNA synthesis, but is independent of inhibition of JNK and calcineurin. Brain Res Mol Brain Res 200I, 97:2I-3I.

8I. Liu J, Albers MW, Wandless TJ, Luan S, Alberg DG, Belshaw PJ, Cohen P, MacKintosh C, Klee CB, Schreiber SL: Inhibition of T cell signaling by immunophilin-ligand complexes correlates with loss of calcineurin phosphatase activity. Biochemistry 1992, 31:3896-390I.

82. Grassberger M, Baumruker T, Enz A, Hiestand P, Hultsch T, Kalthoff F, Schuler W, Schulz M, Werner FJ, Winiski A, et al:: A novel antiinflammatory drug, SDZ ASM 98I, for the treatment of skin diseases: in vitro pharmacology. $\mathrm{Br} /$ Dermatol 1999, I 41:264-273

83. Peterson LB, Cryan JG, Rosa R, Martin MM, Wilusz MB, Sinclair PJ, Wong F, Parsons JN, O'Keefe SJ, Parsons WH, et al.: A tacrolimusrelated immunosuppressant with biochemical properties distinct from those of tacrolimus. Transplantation 1998, 65: $10-18$

84. Dumont FJ, Koprak S, Staruch MJ, Talento A, Koo G, DaSilva C, Sinclair PJ, Wong F, Woods J, Barker J, et al: A tacrolimus-related immunosuppressant with reduced toxicity. Transplantation 1998, 65:18-26

85. Schreiber SL: Chemistry and biology of the immunophilins and their immunosuppressive ligands. Science 199|, 25 I:283-287.

86. Thomson AW, Turnquist HR, Raimondi G: Immunoregulatory functions of mTOR inhibition. Nat Rev Immunol 2009, 9:324-337.

87. Campistol JM: Minimizing the risk of posttransplant malignancy. Transplantation 2009, 87:S19-22.

88. Born TL, Myers JK, Widlanski TS, Rusnak F: 4-(Fluoromethyl)phenyl phosphate acts as a mechanism-based inhibitor of calcineurin. J Biol Chem 1995, 270:2565I-25655.

89. Martin BL: Inhibition of calcineurin by the tyrphostin class of tyrosine kinase inhibitors. Biochem Pharmacol 1998, 56:483-488.

90. Stewart SG, Hill TA, Gilbert J, Ackland SP, Sakoff JA, McCluskey A: Synthesis and biological evaluation of norcantharidin analogues: towards PPI selectivity. Bioorg Med Chem 2007, 15:7301-7310. 
91. Weiser DC, Shenolikar S: Use of protein phosphatase inhibitors. Curr Protoc Protein Sci 2003, Chapter I3(Unit I3): 10.

92. Enz A, Pombo-Villar E: Class II pyrethroids: noninhibitors calcineurin. Biochem Pharmacol 1997, 54:321-323.

93. Fakata KL, Swanson SA, Vorce RL, Stemmer PM: Pyrethroid insecticides as phosphatase inhibitors. Biochem Pharmacol 1998, 55:2017-2022

94. Wang H, Zhou CL, Lei H, Zhang SD, Zheng J, Wei Q: Kaempferol: a new immunosuppressant of calcineurin. IUBMB Life 2008, 60:549-554.

95. Lei $H, Q_{i} Y$, Jia ZG, Lin WL, Wei Q: Studies on the interactions of kaempferol to calcineurin by spectroscopic methods and docking. Biochim Biophys Acta 2009, 1794: I269-1275.

96. Lee S, Kim YJ, Kwon S, Lee Y, Choi SY, Park J, Kwon HJ: Inhibitory effects of flavonoids on TNF-alpha-induced IL-8 gene expression in HEK 293 cells. BMB Rep 2009, 42:265-270.

97. Humar M, Pischke SE, Loop T, Hoetzel A, Schmidt R, Klaas C, Pahl $\mathrm{HL}$, Geiger KK, Pannen BH: Barbiturates directly inhibit the calmodulin/calcineurin complex: a novel mechanism of inhibition of nuclear factor of activated T cells. Mol Pharmacol 2004, 65:350-361.

98. Humar M, Dohrmann H, Stein P, Andriopoulos N, Goebel U, Heimrich B, Roesslein M, Schmidt R, Schwer Cl, Hoetzel A, et al.: Repression of $\mathrm{T}$-cell function by thionamides is mediated by inhibition of the activator protein-1/nuclear factor of activated T-cells pathway and is associated with a common structure. Mol Pharmacol 2007, 72:1647-1656.

99. Loop T, Liu Z, Humar M, Hoetzel A, Benzing A, Pahl HL, Geiger KK, $\mathrm{BH}$ JP: Thiopental inhibits the activation of nuclear factor kappaB. Anesthesiology 2002, 96:1202-1213.

100. Correa-Sales C, Tosta CE, Rizzo LV: The effects of anesthesia with thiopental on $\mathrm{T}$ lymphocyte responses to antigen and mitogens in vivo and in vitro. Int $J$ Immunopharmacol 1997 19:117-128.

I0I. Baba Y, Hirukawa N, Tanohira N, Sodeoka M: Structure-based design of a highly selective catalytic site-directed inhibitor of Ser/Thr protein phosphatase 2B (calcineurin). J Am Chem Soc 2003, I 25:9740-9749.

102. Baba Y, Hirukawa N, Sodeoka M: Optically active cantharidin analogues possessing selective inhibitory activity on Ser/Thr protein phosphatase 2B (calcineurin): implications for the binding mode. Bioorg Med Chem 2005, 13:5 I64-5I70.

103. Carruthers NJ, Dowd MK, Stemmer PM: Gossypol inhibits calcineurin phosphatase activity at multiple sites. Eur J Pharmacol 2007, 555: $106-1 \mid 4$

104. Xu WB, Xu LH, Lu HS, Ou-Yang DY, Shi HJ, Di JF, He XH: The immunosuppressive effect of gossypol in mice is mediated by inhibition of lymphocyte proliferation and by induction of cell apoptosis. Acta Pharmacol Sin 2009, 30:597-604.

105. Weissenmayer B, Boeckeler K, Lahrz A, Mutzel R: The calcineurin inhibitor gossypol impairs growth, cell signalling and development in Dictyostelium discoideum. FEMS Microbiol Lett 2005, 242:19-25.

106. Gomez MS, Piper RC, Hunsaker LA, Royer RE, Deck LM, Makler MT, Jagt DL Vander: Substrate and cofactor specificity and selective inhibition of lactate dehydrogenase from the malarial parasite P. falciparum. Mol Biochem Parasitol 1997, 90:235-246

107. Yu BZ, Rogers J, Ranadive G, Baker S, Wilton DC, Apitz-Castro R, Jain MK: Gossypol modification of Ala-I of secreted phospholipase A2: a probe for the kinetic effects of sulfate glycoconjugates. Biochemistry 1997, 36: I2400-I24II.

108. Adlakha RC, Ashorn CL, Chan D, Zwelling LA: Modulation of 4'-(9acridinylamino)methanesulfon-m-anisidide-induced, topoisomerase II-mediated DNA cleavage by gossypol. Cancer Res 1989, 49:2052-2058.

109. Gualberto A, Marquez G, Carballo M, Youngblood GL, Hunt SW 3rd, Baldwin AS, Sobrino F: p53 transactivation of the HIV-I long terminal repeat is blocked by PD 14 a calcineurin-inhibitor with anti-HIV properties. J Biol Chem 1998, 273(1 2):7088-7093.

110. Brill GM, Premachandran U, Karwowski JP, Henry R, Cwik DK, Traphagen LM, Humphrey PE, Jackson M, Clement Jj, Burres NS, et al: Dibefurin, a novel fungal metabolite inhibiting calcineurin phosphatase activity. J Antibiot (Tokyo) 1996, 49: 124-I 28.

111. Mulero MC, Aubareda A, Orzaez M, Messeguer J, Serrano-Candelas E, Martinez-Hoyer S, Messeguer A, Perez-Paya E, Perez-Riba M: Inhibiting the calcineurin-NFAT (nuclear factor of activated
T cells) signaling pathway with a regulator of calcineurinderived peptide without affecting general calcineurin phosphatase activity. J Biol Chem 2009, 284:9394-940I.

I12. Borisy AA, Elliott PJ, Hurst NW, Lee MS, Lehar J, Price ER, Serbedzija G, Zimmermann GR, Foley MA, Stockwell BR, Keith CT: Systematic discovery of multicomponent therapeutics. Proc Natl Acad Sci USA 2003, 100:7977-7982.

113. Sieber M, Karanik M, Brandt C, Blex C, Podtschaske M, Erdmann F, Rost R, Serfling E, Liebscher J, Patzel M, et al.: Inhibition of calcineurin-NFAT signaling by the pyrazolopyrimidine compound $\mathbf{N C I 3}$. Eur J Immunol 2007, 37:2617-2626.

114. Roehrl MH, Kang S, Aramburu J, Wagner G, Rao A, Hogan PG: Selective inhibition of calcineurin-NFAT signaling by blocking protein-protein interaction with small organic molecules. Proc Natl Acad Sci USA 2004, I $01: 7554-7559$.

II5. Kang S, Li H, Rao A, Hogan PG: Inhibition of the calcineurinNFAT interaction by small organic molecules reflects binding at an allosteric site. J Biol Chem 2005, 280:37698-37706.

1 16. Djuric SW, BaMaung NY, Basha A, Liu H, Luly JR, Madar DJ, Sciotti RJ, Tu NP, Wagenaar FL, Wiedeman PE, et al:: 3,5-Bis(trifluoromethyl)pyrazoles: a novel class of NFAT transcription factor regulator. J Med Chem 2000, 43:2975-298I.

117. Chen Y, Smith ML, Chiou GX, Ballaron S, Sheets MP, Gubbins E, Warrior U, Wilkins J, Surowy C, Nakane M, et al: THI and TH2 cytokine inhibition by 3,5-bis(trifluoromethyl)pyrazoles, a novel class of immunomodulators. Cell Immunol 2002, 220:134-142

I 18. Trevillyan JM, Chiou XG, Chen YW, Ballaron SJ, Sheets MP, Smith ML, Wiedeman PE, Warrior U, Wilkins J, Gubbins EJ, et al.: Potent inhibition of NFAT activation and T cell cytokine production by novel low molecular weight pyrazole compounds. J Biol Chem 200I, 276:48II8-48I26.

119. Ishikawa J, Ohga K, Yoshino T, Takezawa R, Ichikawa A, Kubota H, Yamada T: A pyrazole derivative, YM-58483 potently inhibits store-operated sustained $\mathrm{Ca2}+$ influx and IL-2 production in T lymphocytes. J Immunol 2003, I 70(9):444|-4449.

120. Zitt C, Strauss B, Schwarz EC, Spaeth N, Rast G, Hatzelmann A, Hoth M: Potent inhibition of $\mathrm{Ca}+$ release-activated $\mathrm{Ca} 2+$ channels and T-lymphocyte activation by the pyrazole derivative BTP2. Biol Chem 2004, 279: 12427-12437.

12I. Takezawa R, Cheng H, Beck A, Ishikawa J, Launay P, Kubota H, Kinet JP, Fleig A, Yamada T, Penner R: A pyrazole derivative potently inhibits lymphocyte $\mathrm{Ca2}+$ influx and cytokine production by facilitating transient receptor potential melastatin 4 channel activity. Mol Pharmacol 2006, 69:1413-1420.

122. Yoshino T, Ishikawa J, Ohga K, Morokata T, Takezawa R, Morio H, Okada Y, Honda K, Yamada T: YM-58483 a selective CRAC channel inhibitor, prevents antigen-induced airway eosinophilia and late phase asthmatic responses via Th2 cytokine inhibition in animal models. Eur J Pharmacol 2007, 560(23):225-233.

123. Ohga K, Takezawa R, Arakida Y, Shimizu Y, Ishikawa J: Characterization of YM-58483/BTP2, a novel store-operated Ca2+ entry blocker, on $\mathrm{T}$ cell-mediated immune responses in vivo. Int Immunopharmacol 2008, 8: I787-I792.

124. Steinckwich N, Frippiat JP, Stasia MJ, Erard M, Boxio R, Tankosic C Doignon I, Nusse O: Potent inhibition of store-operated Ca2+ influx and superoxide production in HL60 cells and polymorphonuclear neutrophils by the pyrazole derivative BTP2. Leukoc Biol 2007, 81: 1054-1064.

125. Birsan T, Dambrin C, Marsh KC, Jacobsen W, Djuric SW, Mollison KW, Christians U, Carter GW, Morris RE: Preliminary in vivo pharmacokinetic and pharmacodynamic evaluation of a novel calcineurin-independent inhibitor of NFAT. Transpl Int 2004, I7: $145-150$

126. Nilsson LM, Sun ZW, Nilsson J, Nordstrom I, Chen YW, Molkentin JD, Wide-Swensson D, Hellstrand P, Lydrup ML, Gomez MF: Novel blocker of NFAT activation inhibits IL-6 production in human myometrial arteries and reduces vascular smooth muscle cell proliferation. Am \& Physiol Cell Physiol 2007, 292: $\mathrm{Cl} 167-1178$

127. Jabr RI, Wilson AJ, Riddervold MH, Jenkins AH, Perrino BA, Clapp LH: Nuclear translocation of calcineurin Abeta but not calcineurin Aalpha by platelet-derived growth factor in rat aortic smooth muscle. Am J Physiol Cell Physiol 2007, 292:C22 I3-2225. 
128. Lindstedt R, Ruggiero V, D'Alessio DA, Manganello S, Petronzelli $F$, Stasi MA, Vendetti S, Assandri A, Carminati P, De Santis R: The immunosuppressor st 1959 a 3,5-diaryl-s-triazole derivative, inhibits $T$ cell activation by reducing NFAT nuclear residency. Int J Immunopathol Pharmacol 2009, 22(I):29-42.

129. Mistrello G, Galliani G, Assandri A, Filippeschi S, Bassi L: Immunological profile of DLIII-IT, a new immunosuppressant agent. Immunopharmacology 1985, 10:163-169.

130. Campo S, Arseni B, Rossi S, D'Alessio V, Lu R, Ngoje J, Ahl PL, Bonitz $S$, Mannino R, Di Mitri D, et al:: Efficacy of a nanocochleateencapsulated 3,5-diaryl-s-triazole derivative in a murine model of graft-versus-host disease. Transplantation 2008, 86: $17 \mid-175$.

131. Hogestatt ED, Jonsson BA, Ermund A, Andersson DA, Bjork H, Alexander JP, Cravatt BF, Basbaum Al, Zygmunt PM: Conversion of acetaminophen to the bioactive $\mathrm{N}$-acylphenolamine AM404 via fatty acid amide hydrolase-dependent arachidonic acid conjugation in the nervous system. I Biol Chem 2005, 280:3 |405-3|4|2.

132. Caballero FJ, Navarrete CM, Hess S, Fiebich BL, Appendino G, Macho A, Munoz E, Sancho R: The acetaminophen-derived bioactive $\mathrm{N}$-acylphenolamine AM404 inhibits NFAT by targeting nuclear regulatory events. Biochem Pharmacol 2007 73:1013-1023

133. Roman J, de Arriba AF, Barron S, Michelena P, Giral M, Merlos M, Bailon E, Comalada M, Galvez J, Zarzuelo A, Ramis I: UR-I505 - a new salicylate, blocks $T$ cell activation through nuclear factor of activated T cells. Mol Pharmacol 2007, 72(2):269-279.

134. Bailon E, Roman J, Ramis I, Michelena P, Balsa D, Merlos M, Zarzuelo A, Galvez J, Comalada M: The new salicylate derivative UR-I 505 modulates the Th2/humoral response in a dextran sodium sulphate model of colitis that resembles ulcerative colitis. Pharmacol Sci 2009, 109:315-318.

135. Aceves M, Duenas A, Gomez C, San Vicente E, Crespo MS, GarciaRodriguez C: A new pharmacological effect of salicylates: inhibition of NFAT-dependent transcription. J Immunol 2004 173:572I-5729.

136. Proksch P, Giaisi M, Treiber MK, Palfi K, Merling A, Spring H, Krammer $\mathrm{PH}, \mathrm{Li}-\mathrm{Weber} \mathrm{M}$ : Rocaglamide derivatives are immunosuppressive phytochemicals that target NF-AT activity in T cells. J Immunol 2005, 174:7075-7084.

137. O'Keefe SJ, Tamura J, Kincaid RL, Tocci MJ, O'Neill EA: FK-506- and CsA-sensitive activation of the interleukin-2 promoter by calcineurin. Nature 1992, 357:692-694.

138. Vega Lde L, Munoz E, Calzado MA, Lieb K, Candelario-Jalil E, Gschaidmeir H, Farber L, Mueller W, Stratz T, Fiebich BL: The 5-HT3 receptor antagonist tropisetron inhibits $\mathrm{T}$ cell activation by targeting the calcineurin pathway. Biochem Pharmacol 2005, 70:369-380.

139. Mousavizadeh K, Rahimian R, Fakhfouri G, Aslani FS, Ghafourifar P: Anti-inflammatory effects of 5-HT receptor antagonist, tropisetron on experimental colitis in rats. Eur J Clin Invest 2009, 39:375-383.

140. Venkatesh N, Feng Y, DeDecker B, Yacono P, Golan D, Mitchison T, McKeon F: Chemical genetics to identify NFAT inhibitors: potential of targeting calcium mobilization in immunosuppression. Proc Natl Acad Sci USA 2004, I 01 :8969-8974.

141. Baine Y, Stankunas BM, Miller P, Hobbs C, Tiberio L, Koch J, Yoon K, Sawutz D, Surowy C: Functional characterization of novel IL-2 transcriptional inhibitors. J Immunol 1995, 154:3667-3677.

142. Yang SD, Tallant EA, Cheung WY: Calcineurin is a calmodulindependent protein phosphatase. Biochem Biophys Res Commun 1982, 106:1419-1425.

143. Rusnak F, Beressi AH, Haddy A, Tefferi A: Calcineurin protein phosphatase activity in peripheral blood lymphocytes. Bone Marrow Transplant 1996, 17:309-313.

144. Aussel C, Breittmayer JP, Pelassy C, Bernard A: Calmodulin, a junction between two independent immunosuppressive pathways in Jurkat T cells. J Biol Chem 1995, 270:8032-8036.

145. Jung EJ, Hur M, Kim YL, Lee GH, Kim J, Kim I, Lee M, Han HK, Kim MS, Hwang S, et al:: Oral administration of I, 4-aryl-2-mercaptoimidazole (KRM-III) inhibits $T$ cell proliferation and reduces clinical severity in murine experimental autoimmune encephalomyelitis model. J Pharmacol Exp Ther 2009 in press.
146. Marquez N, Sancho R, Macho A, Calzado MA, Fiebich BL, Munoz E: Caffeic acid phenethyl ester inhibits T-cell activation by targeting both nuclear factor of activated T-cells and NF-kappaB transcription factors. I Pharmacol Exp Ther 2004, 308:993-1001.

147. Ansorge S, Reinhold D, Lendeckel U: Propolis and some of its constituents down-regulate DNA synthesis and inflammatory cytokine production but induce TGF-betal production of human immune cells. Z Naturforsch [C] 2003, 58:580-589.

148. Natarajan K, Singh S, Burke TR Jr, Grunberger D, Aggarwal BB: Caffeic acid phenethyl ester is a potent and specific inhibitor of activation of nuclear transcription factor NF-kappa B. Proc Natl Acad Sci USA 1996, 93:9090-9095.

149. Kuromitsu S, Fukunaga M, Lennard AC, Masuho Y, Nakada S: 3-(13Hydroxytridecyl)-I-[I3-(3-pyridyl)tridecyl]pyridinium chloride (YM-53792), a novel inhibitor of NF-AT activation. Biochem Pharmacol 1997, 54:999-1005.

150. Michne WF, Schroeder JD, Guiles JW, Treasurywala AM, Weigelt CA, Stansberry MF, McAvoy E, Shah CR, Baine Y, Sawutz DG, et al.: Novel inhibitors of the nuclear factor of activated T cells (NFAT)mediated transcription of beta-galactosidase: potential immunosuppressive and antiinflammatory agents. J Med Chem 1995, 38:2557-2569.

15I. Murray CM, Hutchinson R, Bantick JR, Belfield GP, Benjamin AD, Brazma D, Bundick RV, Cook ID, Craggs RI, Edwards S, et al.: Monocarboxylate transporter MCTI is a target for immunosuppression. Nat Chem Biol 2005, I:37I-376.

152. Burres NS, Premachandran U, Hoselton S, Cwik D, Hochlowski JE, Ye Q, Sunga GN, Karwowski JP, Jackson M, Whittern DN, et al:: Simple aromatics identified with a NFAT-lacZ transcription assay for the detection of immunosuppressants. I Antibiot (Tokyo) 1995, 48:380-386.

153. Lee SI, Kim BS, Kim KS, Lee S, Shin KS, Lim JS: Immune-suppressive activity of punicalagin via inhibition of NFAT activation. Biochem Biophys Res Commun 2008, 37 I:799-803.

154. Marquez N, Sancho R, Ballero M, Bremner P, Appendino G, Fiebich $B L$, Heinrich M, Munoz E: Imperatorin inhibits T-cell proliferation by targeting the transcription factor NFAT. Planta Med 2004, 70:1016-1021.

155. Jin HZ, Lee JH, Lee D, Lee HS, Hong YS, Kim YH, Lee JJ: Quinolone alkaloids with inhibitory activity against nuclear factor of activated $\mathbf{T}$ cells from the fruits of Evodia rutaecarpa. Biol Pharm Bull 2004, 27:926-928.

156. Kiem PV, Minh CV, Huong HT, Lee JJ, Lee IS, Kim YH: Phenolic constituents with inhibitory activity against NFAT transcription from Desmos chinensis. Arch Pharm Res 2005, 28: I345-1349.

157. Dat NT, Cai XF, Shen Q, Lee IS, Lee EJ, Park YK, Bae K, Kim YH: Gymnasterkoreayne G, a new inhibitory polyacetylene against NFAT transcription factor from Gymnaster koraiensis. Chem Pharm Bull (Tokyo) 2005, 53: I 194-II 96.

158. Dat NT, Cai XF, Shen Q, Lee IS, Kim YH: New inhibitor against nuclear factor of activated $T$ cells transcription from Ribes fasciculatum var. chinense. Chem Pharm Bull (Tokyo) 2005, 53:114-117.

159. Cai XF, Lee IS, Shen G, Dat NT, Lee JJ, Kim YH: Triterpenoids from Acanthopanax koreanum root and their inhibitory activities on NFAT transcription. Arch Pharm Res 2004, 27:825-828.

160. Cai XF, Lee IS, Dat NT, Shen G, Kang JS, Kim DH, Kim YH: Inhibitory lignans against NFAT transcription factor from Acanthopanax koreanum. Arch Pharm Res 2004, 27:738-74I.

16I. Cai XF, Lee IS, Dat NT, Shen G, Kim YH: Diterpenoids with inhibitory activity against NFAT transcription factor from Acanthopanax koreanum. Phytother Res 2004, 1 8:677-680.

162. Dat NT, Lee IS, Cai XF, Shen G, Kim YH: Oleanane triterpenoids with inhibitory activity against NFAT transcription factor from Liquidambar formosana. Biol Pharm Bull 2004, 27:426-428.

163. Lee IS, Lee HK, Dat NT, Lee MS, Kim JW, Na DS, Kim YH: Lignans with inhibitory activity against NFAT transcription from Schisandra chinensis. Planta Med 2003, 69:63-64.

164. Sagoo JK, Fruman DA, Wesselborg S, Walsh CT, Bierer BE: Competitive inhibition of calcineurin phosphatase activity by its autoinhibitory domain. Biochem J 1996, 320(Pt 3):879-884.

165. Hashimoto Y, Perrino BA, Soderling TR: Identification of an autoinhibitory domain in calcineurin. I Biol Chem 1990, 265:1924-1927. 
166. Perrino BA, Ng LY, Soderling TR: Calcium regulation of calcineurin phosphatase activity by its $B$ subunit and calmodulin. Role of the autoinhibitory domain. J Biol Chem 1995, 270:340-346.

167. Perrino BA: Regulation of calcineurin phosphatase activity by its autoinhibitory domain. Arch Biochem Biophys 1999, 372: $159-165$.

168. Terada H, Matsushita M, Lu YF, Shirai T, Li ST, Tomizawa K, Moriwaki A, Nishio S, Date I, Ohmoto T, Matsui H: Inhibition of excitatory neuronal cell death by cell-permeable calcineurin autoinhibitory peptide. J Neurochem 2003, 87: I |45-I I 5 I.

169. Husain SZ, Grant WM, Gorelick FS, Nathanson MH, Shah AU: Caerulein-induced intracellular pancreatic zymogen activation is dependent on calcineurin. Am J Physiol Gastrointest Liver Physiol 2007, 292:GI594-I599.

170. Feske S, Okamura H, Hogan PG, Rao A: Ca2+/calcineurin signalling in cells of the immune system. Biochem Biophys Res Commun 2003, 3 I I:III7-II32.

17I. Aramburu J, Yaffe MB, Lopez-Rodriguez C, Cantley LC, Hogan PG, Rao A: Affinity-driven peptide selection of an NFAT inhibitor more selective than cyclosporin A. Science 1999, 285:2I 29-2I33.

172. Noguchi H, Matsushita M, Okitsu T, Moriwaki A, Tomizawa K, Kang S, Li ST, Kobayashi N, Matsumoto S, Tanaka K, et al:: A new cell-permeable peptide allows successful allogeneic islet transplantation in mice. Nat Med 2004, 1 0:305-309.

173. Dell'Acqua ML, Dodge KL, Tavalin SJ, Scott JD: Mapping the protein phosphatase-2B anchoring site on AKAP79. Binding and inhibition of phosphatase activity are mediated by residues 3 15-360. J Biol Chem 2002, 277:48796-48802.

174. Lai MM, Burnett PE, Wolosker H, Blackshaw S, Snyder SH: Cain, a novel physiologic protein inhibitor of calcineurin. J Biol Chem 1998, 273:|8325-|833|.

175. Sun L, Youn HD, Loh C, Stolow M, He W, Liu JO: Cabin I, a negative regulator for calcineurin signaling in $T$ lymphocytes. Immunity I998, 8:703-7|I.

176. Harris CD, Ermak G, Davies KJ: Multiple roles of the DSCR I (Adapt78 or RCANI) gene and its protein product calcipressin I (or RCANI) in disease. Cell Mol Life Sci 2005, 62:2477-2486.

177. Chan B, Greenan G, McKeon F, Ellenberger T: Identification of a peptide fragment of DSCRI that competitively inhibits calcineurin activity in vitro and in vivo. Proc Natl Acad Sci USA 2005, 102:13075-13080.

178. Aubareda A, Mulero MC, Perez-Riba M: Functional characterization of the calcipressin I motif that suppresses calcineurinmediated NFAT-dependent cytokine gene expression in human T cells. Cell Signal 2006, I 8:|430-|438.

179. Martinez-Martinez S, Genesca L, Rodriguez A, Raya A, Salichs E, Were F, Lopez-Maderuelo MD, Redondo JM, de la Luna S: The RCAN carboxyl end mediates calcineurin docking-dependent inhibition via a site that dictates binding to substrates and regulators. Proc Natl Acad Sci USA 2009, I 06:6 I I 7-6I 22.

180. Mehta S, Li H, Hogan PG, Cunningham KW: Domain architecture of the regulators of calcineurin (RCANs) and identification of a divergent RCAN in yeast. Mol Cell Biol 2009, 29:2777-2793.

181. Park S, Uesugi M, Verdine GL: A second calcineurin binding site on the NFAT regulatory domain. Proc Natl Acad Sci USA 2000, 97:7130-7135

182. Liu J, Arai K, Arai N: Inhibition of NFATx activation by an oligopeptide: disrupting the interaction of NFATx with calcineurin. J Immunol 200I, I 67:2677-2687.

183. Jang $\mathrm{H}$, Cho EJ, Youn HD: A new calcineurin inhibition domain in Cabin I. Biochem Biophys Res Commun 2007, 359:129-I35.

184. Kingsbury T], Cunningham KW: A conserved family of calcineurin regulators. Genes Dev 2000, I 4: I595-I604.

185. Vega RB, Yang J, Rothermel BA, Bassel-Duby R, Williams RS: Multiple domains of MCIPI contribute to inhibition of calcineurin activity. J Biol Chem 2002, 277:3040I-30407.

186. Boncristiano M, Paccani SR, Barone S, Ulivieri C, Patrussi L, Ilver D, Amedei A, D'Elios MM, Telford JL, Baldari CT: The Helicobacter pylori vacuolating toxin inhibits $T$ cell activation by two independent mechanisms. J Exp Med 2003, I98: | 887-I897.

187. Gebert B, Fischer W, Weiss E, Hoffmann R, Haas R: Helicobacter pylori vacuolating cytotoxin inhibits $T$ lymphocyte activation. Science 2003, 301: 1099-1 I02.
188. Sundrud MS, Torres VJ, Unutmaz D, Cover TL: Inhibition of primary human $T$ cell proliferation by Helicobacter pylori vacuolating toxin ( $\mathrm{VacA}$ ) is independent of VacA effects on IL-2 secretion. Proc Natl Acad Sci USA 2004, I 0 I:7727-7732.

189. Sewald X, Gebert-Vogl B, PrassI S, Barwig I, Weiss E, Fabbri M, Osicka $\mathrm{R}$, Schiemann $M$, Busch DH, Semmrich $M$, et al.: Integrin subunit CDI 8 Is the T-lymphocyte receptor for the Helicobacter pylori vacuolating cytotoxin. Cell Host Microbe 2008, 3:20-29.

190. Miskin JE, Abrams CC, Goatley LC, Dixon LK: A viral mechanism for inhibition of the cellular phosphatase calcineurin. Science 1998, 28 I:562-565.

191. Granja AG, Perkins ND, Revilla Y: A238L inhibits NF-ATc2, NFkappa $B$, and c-Jun activation through a novel mechanism involving protein kinase C-theta-mediated up-regulation of the amino-terminal transactivation domain of p300. J Immunol 2008, I 80:2429-2442

192. Matsuda S, Shibasaki F, Takehana K, Mori H, Nishida E, Koyasu S: Two distinct action mechanisms of immunophilin-ligand complexes for the blockade of T-cell activation. EMBO Rep 2000, I:428-434.

193. Granja AG, Nogal ML, Hurtado C, Vila V, Carrascosa AL, Salas ML, Fresno M, Revilla Y: The viral protein A238L inhibits cyclooxygenase-2 expression through a nuclear factor of activated $T$ cell-dependent transactivation pathway. J Biol Chem 2004, 279:53736-53746.

194. Miskin JE, Abrams CC, Dixon LK: African swine fever virus protein A238L interacts with the cellular phosphatase calcineurin via a binding domain similar to that of NFAT. J Virol 2000, 74:94I2-9420.

195. Tatlock JH, Linton MA, Hou XJ, Kissinger CR, Pelletier LA, Showalter RE, Tempczyk A, Villafranca JE: Structure-based design of novel calcineurin (PP2B) inhibitors. Bioorg Med Chem Lett 1997, 7:1007-1012

196. Bialojan C, Takai A: Inhibitory effect of a marine-sponge toxin, okadaic acid, on protein phosphatases. Specificity and kinetics. Biochem J 1988, 256:283-290.

197. Fruman DA, Klee CB, Bierer BE, Burakoff SJ: Calcineurin phosphatase activity in T lymphocytes is inhibited by FK 506 and cyclosporin A. Proc Natl Acad Sci USA 1992, 89:3686-3690.

198. Sinclair PJ, Wong F, Staruch MJ, Wiederrecht G], Parsons WH, Dumont F, Wyvratt M: Preparation and in vitro activities of naphthyl and indolyl ether derivatives of the FK-506 related immunosuppressive macrolide ascomycin. Bioorg Med Chem Lett 1996, 6:2193-2196

199. Baumgrass R, Weiwad M, Erdmann F, Liu JO, Wunderlich D, Grabley $S$, Fischer G: Reversible inhibition of calcineurin by the polyphenolic aldehyde gossypol. I Biol Chem 200I, 276:479|4-4792I. 